\title{
PREHISTORIC INNOVATIONS: WHEELS AND WHEELED VEHICLES
}

\author{
MÁRIA BONDÁR \\ Hungarian Academy of Sciences, Research Centre for the Humanities, Institute of Archaeology \\ 4, Tóth Kálmán Str, H-1097 Budapest, Hungary \\ bondar.maria@btk.mta.hu
}

\begin{abstract}
Two of the most significant innovations of the fourth millennium BC were the invention of the wheel and of wheeled vehicles, which led to other major innovations during the Late Copper Age. Discussed here are the major milestones and advances in research on wheeled vehicles, problems of dating, and the issues relating to the actual place of the invention of wheeled vehicles as well as the fruitful collaboration between various analytical disciplines and archaeology concerned with the study of wheels and early wheeled vehicles.

I have collected the finds relating to wheels and wheeled vehicles. It would appear that the invention of the wheel and of wheeled conveyances occurred in different centres. Even though we are unable to date the creation of the very first vehicle to the year, it seems quite certain that wheeled vehicles appeared more or less simultaneously in several regions in the fourth millennium BC.

Keywords: Late Copper Age, innovations, early wheels, wheeled vehicles
\end{abstract}

\section{INTRODUCTION ${ }^{1}$}

Today, we tend to associate innovations with the industrial inventions of the twenty-first century that have radically transformed our lives. The new advances in nanotechnology, robotics, genomics and information technology have become part of our daily lives. However, these could hardly have come about without the knowledge and skills accumulated during the previous millennia.

Illiterate prehistoric societies can be credited with countless inventions that continue to determine our lives today, in the space age. These include, to mention but a few, the discovery of fire, the crafting of tools such as projectile points, knives, axes and hammers from various materials, the cultivation of plants, the domestication of various animals, the technology of potting, the various modes of food storage as well as the different technologies for the preservation and processing of food, the elements of clothing (wool and textile production, leather tanning, footwear, jewellery), house construction, prospecting for raw materials, the discovery of metal casting and of alloys, the exploitation of salt mines, and communication between communities.

The perhaps two most significant innovations of the Late Copper Age (3600/3500-3000/2800 BC) were the invention of the wheel and of wheeled vehicles, which sparked further major inventions in this early period. The new device was no doubt born after long experimentation driven by practical needs and was initially conceived and perfected with meticulous attention to detail to ensure its adaptation to local geographic conditions and the expectations and needs of the community.

${ }^{1}$ This study is based on the paper read at the conference "Far-sighted scholarship - Meaningful answers for the future. Migration, change and continuity - Insights from past millennia for the fu- ture" organised as part of the Celebration of Hungarian Science in November 2014 
It seems likely that our ancestors first created simple wooden sledges, slides, two-wheeled carts and contraptions for transporting agricultural produce. The latter turned out to be so practical that they are still used today in Anatolia and the Pyrenees. ${ }^{2}$

Four-wheeled wagons with a rectangular vehicle body fitted with solid disc wheels or tripartite wheels made from three planks mortised to the axle can be regarded as the perfected version. This vehicle proved to be highly practical and its variants - carts and peasant wagons - are still around today. These heavy wagons and carts were most often drawn by two animals, usually oxen, while horses were generally harnessed to its later variant, the two-wheeled light chariot. Draught animals varied from one region or continent to the other, and the currently known depictions show a wide array of creatures associated with vehicles, ranging from birds to camels.

Vehicles, the period's major invention, were initially the privilege of a few for it expressed prestige and exceptional social status that was also vested with a sacral meaning by their owners. As mystical symbols, wheels and wagons were the links between earthly existence and the celestial sphere, and their owners were the select few who could boast direct connections with mystical powers. The mythologies and religions of later ages speak of the carriages of the gods, of vehicles flown to the heavens by birds, ${ }^{3}$ and of chariots of the Sun cult, ${ }^{4}$ while the legends and folk tales of various peoples allude to funerary wagons on which the deceased made the journey to the otherworld.

\section{MAJOR MILESTONES AND RESEARCH THEMES OF PREVIOUS STUDIES ON WHEELED VEHICLES}

It still remains to be established when and where the first wheel and the associated wooden structure first appeared. Was it diffused from one centre to other parts of the world or were wheeled vehicles invented in several places, independently of each other?

Several studies and books have been devoted to the origins and early history of wheels and wheeled conveyances, discussing these issues from various perspectives. Here, I shall highlight the main milestones, which still have a theoretical relevance regarding origins and dating.

The archaeological evidence for early vehicles was first reviewed by V. Gordon Childe, the renowned Australian professor of archaeology, who discussed these finds in several of his works. ${ }^{5}$ The accepted chronological framework was based on the early Egyptian dynasties and the Mesopotamian king lists, to which the European finds could be anchored based on the occurrence of similar artefacts and ornamentations. ${ }^{6}$

From his survey of the then known relics scattered over an immense area (remains of genuine wheeled vehicles, miniature models, depictions on reliefs and literary references) and their dating, Childe concluded that the earliest evidence comes from Mesopotamia, implying that wheeled conveyances had been invented in that region, whence they spread to other parts of the world during the ensuing centuries, in the following sequence (according to the then known dates): the earliest finds from Mesopotamia could be dated to $3000+\mathrm{BC}$, to $2500 \pm \mathrm{BC}$ from the Indus Valley, to $2500 \mathrm{BC}$ from the Central Asian steppe, to $2200 \pm 100 \mathrm{BC}$ from Syria and the Upper Euphrates region, to $2000 \pm 100 \mathrm{BC}$ from the Orontes region, to $1900 \pm 100 \mathrm{BC}$ from Crete and Central Anatolia, to $1550 \pm 30 \mathrm{BC}$ from mainland Greece, to $1400 \pm 200 \mathrm{BC}$ from Armenia and southern Russia, to $1100 \pm 200 \mathrm{BC}$ from northern Italy, to $1000 \pm 200$ from Central and Northern Europe, and to $500 \pm 100$ BC from Britain. ${ }^{7}$

This apparently secure chronological matrix could have been revised some two years after Childe's study. In 1953, two miniature wagon models came to light from well-datable, secure contexts in the Late Copper Age cemetery of Budakalász, a site lying in the heartland of Europe, which were almost immediately published by the excavator. ${ }^{8}$ Being much earlier, these two wagon models were at variance with the regional and chronological scheme proposed by Childe and furnished new evidence that four-wheeled wagons had appeared at an early date in

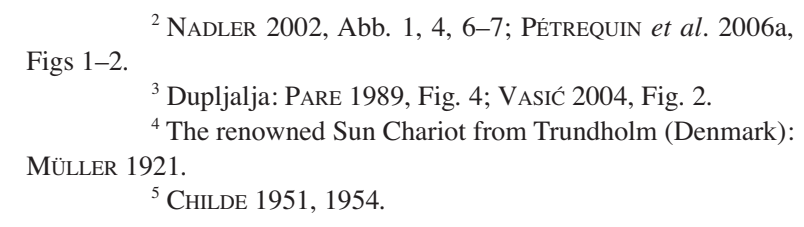

Acta Archaeologica Academiae Scientiarum Hungaricae 69, 2018
${ }^{6}$ The perhaps most eloquent example is the correlation of the three Late Copper Age anthropomorphic urns found at Ózd-Center with Troy V, which also yielded anthropomorphic urns that bear some resemblance to the exemplars found at Ózd (KALICZ 1963). Today, this correlation is little more than an interesting curio of research history since we now know that Troy did not even exist at the time.

${ }^{7}$ CHILDE 1951, 193.

${ }^{8}$ SOPRONI 1954 
Europe. However, the Hungarian article was insufficient for challenging Childe's influential theoretical model, as was János Banner's monograph publishing the cemetery's first discovered 115 burials and Sándor Soproni's study on the wagon model in German. ${ }^{9}$

The miniature wheel and wagon models sculpted from clay brought to light in the Carpathian Basin became known through István Bóna's oft-cited study written in English in the 1960s. ${ }^{10}$ Although Bóna convincingly demonstrated the early European presence of four-wheeled vehicles, he did not challenge the notion that their invention had occurred in Mesopotamia. ${ }^{11}$

The comprehensive studies by Childe and Bóna gave a fresh impetus to research on prehistoric wheeled vehicles. The publication of new finds, principally wagon models, considerably enriched our knowledge. A spate of important articles and studies covered the formal traits, the distribution and the possible ritual role of wheeled vehicles, and sought an answer to how and for what purposes miniature models were used, citing mythological and religious examples from later ages to illustrate their association with various deities and the otherworld. Miniature models are generally interpreted as ritual objects, although their original function continues to elude us in the lack of palpable evidence from secure contexts. Various models have been proposed for the routes whereby wheeled vehicles spread and for the duration of their diffusion - some of these invoked an origin in the east, although the general scholarly consensus that their origin lay somewhere in the Fertile Crescent remained unchanged.

Accepting the Mesopotamian origin of wheeled conveyances, Emmanuel Anati focused on the twowheeled war chariots of the European Bronze Age. ${ }^{12}$ Stuart Piggott devoted several studies to the occurrence and distribution of wheeled conveyances, with a special interest in the horse-drawn wheeled vehicles of the Far East and China. ${ }^{13}$ The vehicles of the Near East were intensely researched by Mary A. Littauer and Joost H. Crouwel, who covered this subject in a series of comprehensive studies. ${ }^{14}$ Wolfram Nagel and Peter Roger Stuart Moorey's work in this field likewise focused on the same region. ${ }^{15}$ The wheeled conveyances of the steppe region were principally reviewed and discussed in detail by Alexander Häusler. ${ }^{16}$

Following the surge of interest in the 1960s and 1970s, studies on early wheeled vehicles received a fresh impetus from the findings of another discipline.

\section{OTHER INNOVATIONS ASSOCIATED WITH WHEELED VEHICLES}

Simultaneously with the advances made in archaeological studies, archaeozoological inquiries into the earliest traces of the domestication of the horse yielded exciting new results, some of which had major implications for the study of wheeled vehicles.

The assessment of the archaeozoological material from the large Neolithic sites in southern Europe during the 1970s revealed that the domesticates of the first wave of domestication, principally sheep, goat and pig, were represented by bones from young, no more than a few months old individuals, implying that the animals had been slaughtered for their meat before reaching adulthood. In contrast, the archaeozoological samples from communities familiar with wheeled vehicles contained the bones of older cattle because only oxen, castrated bulls, could be yoked to wagons as draught animals. These animals were not only kept for a longer period of time, but they were also trained to pull wagons and to wear yokes, an indication that animal raising had entered a new dimension: in the wake of the training they underwent, the animals' value increased and the range of their exploitation was broadened and significantly transformed. The realisation that domesticates need not be immediately slaughtered led to more selective breeding strategies, of which one important milestone was the exploitation of the animals' traction power, which also led to morphological alterations on their bones.

In an influential study published in 1981, Andrew Sherratt coined the term "Secondary Products Revolution" (SRP) for describing the exploitation of domestic animals for a variety of purposes other than simply the consumption of their meat: ${ }^{17}$ for their milk, their wool, their traction power, all of which were repeatedly exploitable

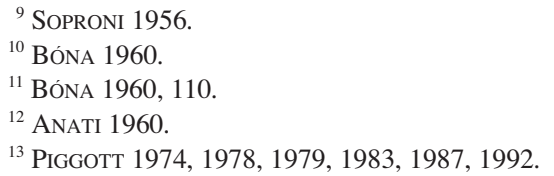

${ }^{9}$ SOPRONI 1956.

${ }^{11}$ BÓNA 1960, 110

${ }^{13}$ Piggott 1974, 1978, 1979, 1983, 1987, 1992

${ }^{14}$ LitTauer-Crouwel 1974, 1979, 1990, 2002 (a collection of previously published articles).

${ }^{15}$ NAGEL 1966, 1986, 1992; MoORey 1986.

${ }^{16}$ HÄUSLER 1978, 1981, 1984, 1985, 1986, 1992.

${ }^{17}$ SherRatT 1981.

Acta Archaeologica Academiae Scientiarum Hungaricae 69, 2018 
resources, making the lives of communities breeding various domesticates easier and wealthier in addition to giving them the option of planning ahead. The community's meat supply no longer depended solely on the success of hunting, which now merely enriched the variety of available meat types. This change inspired various economic strategies among different communities. The availability of the meat of bred animals that could be slaughtered anytime stimulated experimentation with different cooking, roasting, preservation and spicing technologies and their perfection. The various techniques of leather and bone working too were enriched with new procedures and the sophisticated art of tanning is probably an innovation that can also be linked to this period. The use of animal milks enabled the production of various milk-based products such as cheese and butter that were probably consumed by this time.

Sherratt contended that the changes in the earlier fourth millennium BC were on a scale on par with Childe's Neolithic Revolution: the period saw new inventions and innovations such as the wheel, wheeled vehicles and the ard plough, and the spread of new domestic species such as horse, ass and woolly sheep. Sherratt elaborated on his original SPR model in several studies and he envisioned the period's communities as part of an almost gigantic industrial society in his Secondary Products Scenario. ${ }^{18}$

Sherratt's influential model gave a fresh impetus to the period's scholarship. The number of publications presenting new finds grew substantially, and due emphasis was placed on the dating and interpretation of these finds, the search for the homeland of the new invention, the problems related to the domestication of the horse and the origins of the Indo-European peoples. The possible link between wheeled vehicles and the horse has since long enjoyed a prominent position on research agendas. The studies on the domestication of the horse and on the origins of the Indo-European (and the Indo-Iranian) peoples would alone fill a smaller library. ${ }^{19} \mathrm{New}$ advances in the archaeology of the steppe and the region's new finds have been covered by Elena F. Kuz'miná ${ }^{20}$ and Philip Kohl, ${ }^{21}$ while Antonio Sagona has reviewed the assemblages from the steppe regions beyond the Caucasus. ${ }^{22}$ A new Copper Age wagon model from Turkmenistan in Central Asia was recently published by Lyubov Kirtcho. ${ }^{23}$

\section{THE IMPACT OF THE NATURAL SCIENCES ON THE STUDY OF WHEELED VEHICLES}

\subsection{Chronology}

In order to pinpoint where wheeled vehicles were "invented", we need to determine their earliest occurrence, which in turn calls for precise dating. One of the vexing problems of archaeology is dating, which has seen incredible advances during the past six decades.

The radiocarbon revolution occurred soon after World War 2, in the wake of the procedure elaborated at the University of Chicago in 1949. The archaeological application of the radiocarbon dating method published in 1952 by Willard Frank Libby, winner of the Nobel Prize for chemistry, placed archaeological dating on an entirely new footing based on 217 measurements and ultimately overturned the traditional chronological framework. ${ }^{24}$

The Late Copper Age of the Carpathian Basin was assigned to between 2100 and 1900 BC in the historical chronology, which corresponded to the $\mathrm{VI}^{\text {th }}$ Dynasty and the First Intermediate Period of the Old Kingdom in Egypt, to the III ${ }^{\text {rd }}$ Dynasty of Ur preceding the Old Babylonian period in Mesopotamia and to Troy III-V.

However, the radiocarbon dates suggested that the Late Copper Age in the Carpathian Basin should be assigned to between 3600/3500 and 3000 or $2800 \mathrm{BC}$ (as more recently suggested), which can be correlated with the onset of the Pre-Dynastic period in Egypt and the Early and Middle Uruk period in Mesopotamia. Troy did not exist at this time and various prehistoric communities flourished in Europe.

A "gap" of some one thousand years appeared between the traditional historical (short) chronology and the radiocarbon (long) chronology regarding the correlations with the absolute dates of various regions. Although several theoretical models were proposed for bridging this gap, only more recently has a scholarly consensus emerged regarding the synchronisation of the chronological sequences of Europe, the Near East and Egypt.

\footnotetext{
${ }^{18}$ ShERRATT 1983, 1997, 2004.

${ }^{19}$ To mention but a few: Anthony 1990, 1995, 2007, 2008; Rolle 1991; ANTHONY-VinOGRAdov 1995; RAUlWing 2000.

${ }^{20}$ KUZ'MINÁ 2007.
}

\footnotetext{
${ }^{21}$ KOHL 2007.

${ }^{22}$ SAGONa 2013.

${ }^{23}$ KIRTCHO 2009.

${ }^{24}$ LiBBy 1952.
} 
In studies on wheeled vehicles, radiocarbon dating only brought a major breakthrough at the close of the twentieth century, some fifty years after the introduction of this dating method.

A study published in 'Antiquity' in 1999 surveyed the radiocarbon-dated early finds from various regions. The springboard of the study by Jan Albert Bakker, Janusz Kruk, Albert E. Lanting and Sarunas Milisauskas was that the dates for the clay tablets bearing depictions of two-wheeled carts from Uruak-Eanna Layer IVa and from Tell Uquair (?) published in 1936 submitted for radiocarbon dating to the Heidelberg laboratory in 1965 were considerably earlier, around $c a$. 3200-3100 BC, than the date of the other known wagon models. Owing to these early dates, the tablets were again submitted for radiocarbon measurements, which yielded similarly early dates of 3517 $3370 \mathrm{cal}$ BC. Moreover, new evidence for the use of wheeled vehicles in Europe from contexts that could be radiocarbon dated provided an opportunity for a direct comparison of the European and Anatolian dates instead of the earlier cross-datings.

Aside from the clay tablets, the dates of four finds from four different regions were published in the study. In 1974, Bakker found the fragment of a miniature wheel made from limestone dating from the late Uruk period at Jebel Aruda in Syria. ${ }^{25}$ The three radiocarbon dates for the site also dated the wheel model fragment. A securely dated, miniature clay wheel model from the late Uruk period came to light at Arslantepe in Turkey. ${ }^{26} \mathrm{~A}$ vessel bearing a four-wheeled vehicle depiction found in a securely datable context at Bronocice near Cracow was published in $1982 .{ }^{27}$ In addition to the two vessel fragments, the pit yielded additional vessel fragments with symbols of fourwheeled vehicles. ${ }^{28}$ The finds could be assigned to the Funnel Beaker culture. In 1992, a $20 \mathrm{~m}$ long section of a cart track consisting of parallel wheel ruts was identified in a megalithic burial of the Funnel Beaker culture at Flintbek in Germany, ${ }^{29}$ which was dated to $3650-3400 \mathrm{cal} \mathrm{BC} .{ }^{30}$

In addition to these finds, a series of other radiocarbon dates for various other finds were also included, namely nineteen dates for the Uruk, Jebel Aruda, Arslantepe, Flintbek and Bronocice sites. ${ }^{31}$ The measurements were meticulously checked using the most up-to-date techniques. The dates provided by the Heidelberg laboratory (Hd, Germany), the AMS laboratory in Groningen (GrN, The Netherlands) and by the Dicarb Radioisotope Company (DIC, Gainesville, Florida, USA) were published with $1 \sigma$ and $2 \sigma$ calibrated age ranges alongside the mean values. The dates were calibrated using the CAL25 programme, the best available at the time based on the INTCAL98 programme, in the Groningen computer laboratory. The results were checked against the DIC MASCA calibration curve, and thus the surprising final dates were obtained after repeatedly and rigorously checking the results. ${ }^{32}$ The finds from Uruk, Flintbek and Bronocice all fell into the period between 3500-3351 cal BC, the implication being that the Mesopotamian and European evidence for the use of wheeled vehicles was essentially contemporaneous. ${ }^{33}$

A tribute to Lanting's work and his achievements appeared in 2006, revealing that he had since long been preoccupied with the problem of when and where wheeled vehicles had first appeared. He corresponded extensively with scholars working in Europe and Asia Minor in order to keep abreast of new finds and he systematically collected data relating to wheeled conveyances from the archaeological literature. He wrote the bulk of the paper published in 'Antiquity'. ${ }^{34}$ Despite the testimony of the new radiocarbon dates, the study's final conclusion was that wheeled vehicles had spread to Europe from Mesopotamia. ${ }^{35}$ Although Lanting later revised his views, he did not pen them in a new article and his opinion is only known from a letter addressed to Bakker: "The striking result, then, is that the European evidence for the use of wheeled vehicles (including that from Majkop-Novoswobodnaya) is clearly older than that from the Near East. True, this does not necessarily mean that our original ex oriente lux theory was wrong - for new evidence may turn up - but when exclusively based on the known data, 'Europe' obviously wins." 36

Thus, the ex oriente lux model on the origins of European civilisation remained virtually unchallenged, even though the first doubts definitely began to emerge.

${ }^{25}$ BAKKER et al. 1999, Fig. 4.

${ }^{26}$ BAKKer et al. 1999, Fig. 5.

${ }^{27}$ BAKKER et al. 1999, 784-785.

${ }^{28}$ BAKKer et al. 1999, Fig. 7.

${ }^{29}$ BAKKER et al. 1999, Fig. 6.

${ }^{30}$ BAKKER et al. 784. Lanting cited the date from M. Baldia's paper read at a conference in 1995, which was in print at the time.

${ }^{31}$ BAKKER et al. 1999, Table 1, Fig. 3.

${ }^{32}$ BAKKER et al. 1999, 778, note 3.
${ }^{33}$ BAKKER et al. 1999, 786-787. This again suggests that the invention of wheels and wheeled vehicles had occurred in several regions independently of each other - however, the authors were apparently reluctant to commit this conclusion to writing.

${ }^{34}$ DRENTH-BAKKeR 2006, 4, 6. The unedited version of the manuscript submitted to 'Antiquity' is appended to the article (Appendix 1), which differs from the published, edited version in several respects.

${ }^{35}$ BAKKER et al. 1999, 788.

${ }^{36}$ Drenth-BAKKer 2006, 29, Appendix 2.

Acta Archaeologica Academiae Scientiarum Hungaricae 69, 2018 


\subsection{The growth of the archaeological record}

The first comprehensive surveys contained archaeological finds: pictograms from Asia Minor, a handful of wagon and wheel models, combat scenes painted on vases and textual references, alongside royal burials from Mesopotamia and genuine wagon burials from the steppe (Tri Brata) dating from various periods.

Direct and indirect evidence for the use of wheeled vehicles has increased substantially from various regions and periods, from Africa ${ }^{37}$ to India, ${ }^{38}$ from Spain ${ }^{39}$ to Northern Europe, ${ }^{40}$ from Anatolia ${ }^{41}$ to Central Europe, ${ }^{42}$ and from the Caucasus ${ }^{43}$ to Siberia. ${ }^{44}$ Many different types of finds attest to a familiarity with this major innovation.

We know of battle scenes painted onto walls or depicted on mosaics. ${ }^{45}$ Aside from the portrayals of wheels and wagons, of animals yoked to wagons and of ard ploughs among the petroglyphs and painted scenes at Val Camonica in Italy, similar depictions are known from Africa to Albania, too. ${ }^{46}$ In addition to the miniature models of genuine wagons ${ }^{47}$ and depictions of wheeled conveyances incised onto clay vessels, ${ }^{48}$ the existence and use of wagons is also confirmed by the small clay or metal figurines of yoked draught animals. ${ }^{49}$

The evidence attesting to wheeled vehicles has been enlarged by the findings of studies on animal bones: visible marks of traction-induced pathologies, the morphological alterations caused by yoking, could now be added to the research arsenal. ${ }^{50}$

In the wake of the growing number of archaeological finds, the discoveries made by archaeozoologists, the wide-ranging impact of Sherratt's seminal model and the revolutionary changes in dating methods, a series of international conferences were held to survey the state of research in the light of new finds and the new chronological framework. ${ }^{51}$

A conference at which the wooden remains of a genuine wagon were presented was organised at Hammenhofen in 2001, which principally focused on the finds from the German-speaking lands. ${ }^{52}$

The Frasnois symposium in France organised by the French National Centre for Scientific Research (CNRS) in 2002 explored the state of research from the perspective of archaeology and archaeozoology, and strove to demonstrate the joint use of wheels and animal traction power based, for example, on surviving plough furrows and the use of travoises. ${ }^{53}$ The papers read at the conference offered an overview of the newest finds from the Atlantic coast (Ireland) through the Alps and Central Europe to the Black Sea and the Near East, and explored the material relics, the diffusion and the cultural impact of this major innovation from the perspective of both the archaeological and archaeozoological record relating to wheeled vehicles. In addition to the wealth of new material, another major advance was the discussion of the pathological alterations on animal bones and joints that could be clearly associated with harnessing and yoking.

Coupling wheels and animal traction power was not restricted to wheeled conveyances. The combination of wheels and animal power worked well in various other wakes of life too, and this discovery was probably made at a fairly early time, as demonstrated by some of the conference's speakers. Yokes were not merely the fixtures of wagons and carts, but also of A-framed, two-wheeled travoises for transporting produce. ${ }^{54}$

\footnotetext{
${ }^{37}$ GAUTHIER-GAUTHIER 2011.

${ }^{38}$ KeNOYer 2004; LAW 2006.

${ }^{39}$ SANZ 2005.

${ }^{40}$ LARSSON 2004; JOHANNSEN-LAURSEN 2010; LinGUHNÉR 2014

${ }^{41}$ LitTAUER-Crouwel 1990, 2002; NAGel 1986, 1992; MOOREY 1986; GREENBERG 2014.

${ }^{42}$ For comprehensive discussions, see BÓNA 1992; PiggotT 1992; Vosteen 1996, 1999; BorofFKa 2004; BondáR 2004, 2006, 2012; BONDÁR-SZÉKELY 2011; BURMEISTER 2004, 2011; MISCHKA 2011.

${ }^{43}$ Maran 2004a; Gej 2004; Trifonov 2004; Ivanova 2007, 2012.

${ }^{44}$ Novozhenov 2012.

${ }^{45}$ For a recent overview of chariot depictions, and particularly of so-called chariot scenes, see FeLdMAN-SAuvage 2010.

${ }^{46}$ FORNI 1988; Woytowich 1995; Fedele 2006; KorkUTI 2008; ANATI 2014.
}

${ }^{47}$ BONDÁR 2012.

${ }^{48}$ Bronocice: KruK-Milisauskas 1982, Abb. 1; Ostrowiecz: Vosteen 1999, Taf. 93. 56; Dopiewo: PrzybyL 2015, Fig. 9. All three sites are located in Poland.

${ }^{49}$ BOROFFKA 2004; BONDÁR 2012

${ }^{50}$ TARRUS et al. 2006, 25-30. The volume contains several other archaeozoological studies.

${ }^{51}$ Rad und Wagen 2002; WegZeiten 2004; Rad und Wagen 2004; Premiers chariots, premiers araires 2006; Between the Aegean and Baltic Seas 2007.

${ }^{52}$ Rad und Wagen 2002.

${ }^{53}$ The conference volume of the Frasnois conference (Premiers chariots, premiers araires 2006) was dedicated to Andrew Sherratt, who sadly was no longer with us by the time it was published.

${ }^{54}$ Fedele 2006; Saulieu-Serres 2006, Fig. 14. The many scenes among the rock engravings include one with a wagon and a depiction of ploughing with animals. 
Presented at the conference were timber trackways, wheel ruts and wooden wheel and axle remains, alongside visible traces of ploughing, wooden ard ploughs and petroglyphs. The new finds and the advances made in radiocarbon dating led to a fresh look at previous archaeological interpretations. The securely dated finds provided conclusive evidence that wheels and wheeled conveyances had quite certainly appeared by the later fourth millennium BC in Europe. The concluding study of the Frasnois conference ${ }^{55}$ described the three major models on the origins and the direction of the diffusion of wheeled vehicles proposed by Sherratt, Irenäus Matuschik and Markus Vosteen, respectively, for illustrating the main theoretical contentions. In Sherratt's view, wheeled vehicles first appeared in Mesopotamia around 4000 BC, whence they spread to Europe during the ensuing five hundred years. In contrast, Matuschik contended that wheeled vehicles made their first appearance on the northern Pontic coast around $3800 \mathrm{BC}$, from where they spread in two directions, towards Europe and Anatolia during three hundred years, while Vosteen argued that wheeled vehicles appeared roughly simultaneously in Mesopotamia and the Carpathian Basin around $3500 \mathrm{BC}$ and that this innovation then spread in various directions from these two centres. ${ }^{56}$

Regrettably, this synthesising interdisciplinary conference did not receive due attention in scholarship because the conference volume was only published in $2006 .{ }^{57}$

The conference held in Oldenburg (Germany) in 2004 had a greater impact on archaeological scholarship than the Frasnois symposium. The Oldenburg conference was accompanied by a magnificent archaeological exhibition at which the earliest finds evidencing the use of wheeled vehicles were displayed alongside the new dating results. The catalogue to the exhibition published in Oldenburg ${ }^{58}$ and the compendium of studies based on the papers read at the conference published in Mannheim ${ }^{59}$ covered virtually all aspects of the conference's theme. Many new research findings brought a major paradigm shift and the growing corpus of finds shed new light on earlier widely accepted theories. Childe's monocentric model, according to which wheeled vehicles were invented in the urban cultures of southern Mesopotamia, began to be strongly challenged. Several scholars argued that wheeled vehicles had been invented independently of each other in multiple centres. ${ }^{60}$

The elaborate models proposed by Sherratt and Joseph Maran have several points in common, but differ regarding the route of diffusion. Both see the fourth millennium BC, and especially its later half, as a period of intensive supra-regional contacts and transformations. Both focus on the social receptiveness to the innovation rather than merely its adoption, examining what would today be called a "technological transfer" as part of a broader package. They regard the "Uruk expansion" as a key phenomenon in the diffusion of wheeled vehicles. Sherratt's main argument was that the use of animal-drawn wagons was only conceivable in regions with a concentration of various resources such as livestock, goods and manpower, and thus vehicles were essentially used by the elite. He noted that a concentration of resources can only be observed in the early urban centres of southern Mesopotamia and thus the spread of the technology, including the package of animal-drawn ploughs and wheeled vehicles, proceeded from south to north on the elite level. He believed that the SPR innovations first appeared in Asia Minor and the Near East, whence they spread to Europe and certain regions of Asia during the fourth millennium BC. ${ }^{61}$

In contrast, Maran claimed that wheeled vehicles were invented on the northern Pontic coast and were subsequently diffused from that region. In his view, the technology of wheeled vehicles was mediated southward by the Maikop culture of the Caucasus, known to be contemporaneous with the Middle and Late Uruk period. Maran too agreed that this technology transfer occurred on an elite level. ${ }^{62}$

On the testimony of these conferences and exhibitions, the evidence for wheeled vehicles has increased enormously and continues to grow. Excavations have brought to light the remains of genuine wagons ${ }^{63}$ wooden wheels ${ }^{64}$ and axles ${ }^{65}$ a wooden wagon model with clay wheels from a child burial, ${ }^{66}$ clay wheel models, ${ }^{67}$ wheel ruts

${ }^{55}$ Pétrquin-Pétrequin-Bailly 2006, Fig. 4.

${ }^{56}$ Pétrquin-PÉTREQuin-BAILly 2006, 363-366.

${ }^{57}$ PÉtReQuin et al. (eds) 2006.

${ }^{58}$ Rad und Wagen 2004.

${ }^{59}$ FANSA-BURMEISTER (eds) 2004b. The conference volume was published in 2004, the year of the conference, and it is therefore better known and more often cited than the volume of the earlier Frasnois conference held in 2002, whose volume only appeared in 2006.

${ }^{60}$ BuRMEISTER 2004.

${ }^{61}$ Sherratt 2004, 421-423. 2011, Abb. 19)

${ }^{62}$ Maran 2004b, 436-438.

${ }^{63}$ From Russia (Trifonov 2004, Abb. 2; Burmeister

${ }^{64}$ From The Netherlands (Rad und Wagen 2004, Abb. 3839; PÉTREQuin et al. 2006b, Fig. 7.1; KoOIJMANs 2006, Figs 4-5), from Germany (Rad und Wagen 2004, 6, Abb. 80; PÉTREQUin et al. 2006, Fig. 7. 2; Schlichtherle 2006, Fig. 3; Schlichtherle 2010, Abb. 4), from Switzerland (Rad und Wagen 2004, Abb. 37, PÉTREQUin et al. 2006b, Fig. 3; Ruoff 2006, Fig. 1), from Slovenia (Rad und Wagen 2004, Abb. 41) and from Denmark (Rad und Wagen 2004, Abb. 42).

Acta Archaeologica Academiae Scientiarum Hungaricae 69, 2018 
in a megalithic grave ${ }^{68}$ and timber trackways ${ }^{69}$ The radiocarbon dates for these finds provided incontestable evidence that wheeled vehicles had appeared and been used simultaneously in several regions lying far from each other.

\section{THE CURRENT STATE OF RESEARCH: UNCERTAINTIES AND TESTIMONIES}

\subsection{Wagon burials: misinterpreted constructs in the Carpathian Basin}

One of the oft-encountered commonplaces in the archaeological literature and various other publications is that the cattle pairs found in the Alsónémedi and Budakalász cemeteries had in fact been part of genuine wagon burials (Alsónémedi, Grave 3: two humans and two cattle; Grave 28: one human and two cattle; Budakalász, Grave 3: two humans and two cattle).

This interpretation has been challenged on two counts. Christian Jeunesse surveyed the paired cattle burials with a focus on the burial mode, the form of the grave pit and the associated grave goods. He registered and analysed twenty-two paired cattle burials from Germany, Poland and Hungary, from which he concluded that there was nothing in the graves indicating the presence of a wagon and that the burial of the cattle pairs was rather an expression of their owners' prestige. ${ }^{70}$

Exploring the significance of paired cattle interments on the Jütland peninsula and comparing them to the similar burials in the central regions of Europe, Niels Johanssen and Steffen Laursen similarly found no evidence for the one-time presence of wagons in the graves. ${ }^{71}$

József Korek, who had conducted the excavations at Alsónémedi and had later published the finds, contended that the paired cattle burials in Graves 3 and 28 had been sacrificial animals. ${ }^{72}$ A quern stone lay beside the larger animal in Grave 28, which in Korek's view was an indication that the animal had been a domestic species. The paired cattle burials uncovered in the cemetery both contained domestic species whose blood had been used as part of the sacrifice. Korek noted that Banner had uncovered five complete cattle skeletons in one of the Baden refuse pits at Hódmezővásárhely-Bodzáspart. The animals had been deposited with their legs drawn up into a contracted position. A similarly complete cattle skeleton was found in one of the settlement pits at Üllő. ${ }^{73}$ Korek interpreted Graves 3 and 28 of Alsónémedi as chieftain's burials, which seemed to be confirmed by the presence of the animals and the richness of the grave inventories compared to the other burials. The two graves lay in the central part of the hillock accommodating the burial ground, which was another indication of their special status. ${ }^{74}$ According to Sándor Bökönyi, one of the animals in each grave was a cow, while the other was a young calf. ${ }^{75}$ We know that young animals are unsuitable for traction, while cows were dairy animals that were far too valuable to the community to be used as draught animals, and thus their burial can hardly be interpreted as wagon burials, but should rather be seen as an expression of prestige, the very reason that Korek regarded the two burials as chieftain's graves. In his later studies, Korek too addressed the issue whether paired cattle burials should be equated with wagon burials, an interpretation first proposed by Banner in relation to Grave 3 of the Budakalász cemetery, ${ }^{76}$ which was later cited as a proven fact by József Csalog. ${ }^{77}$

In his later works, Korek maintained his earlier contention that although it would be tempting to interpret the burials as wagon burials, there were no soil marks in the graves indicating the remains of organic material. The

${ }^{65}$ From Germany (Rad und Wagen 2004, 6, Abb. 40, 43-46; SCHLiCHTHERLE 2010, Abb. 8), from Slovenia (VELUŠČEK 2002; Rad und Wagen 2004, Abb. 41) and from Switzerland (RUOFF 2006, Fig. 1). Fig. 11).

${ }^{66}$ From Turkmenistan, from a child burial (KIRTCHO 2009,

From Denmark (Rad und Wagen 2004, Abb. 47), Gerund Wagen 2004, Abb. 51), Russia (BurmeISTER 2011 Abb. 20), Romania (BurmeIster 2011, Abb. 23) and Turkmenistan (KIRTCHO 2009, Fig. 19).

${ }^{68}$ Flintbek (ZICH 1992, 1993, 2006, Figs 3-5).
${ }^{69}$ From Germany (Rad und Wagen 2004, Abb. 52; Burmeister 2006, Figs 3-8; SchlichtHerLe 2010, Abb. 10), Switzerland (Rad und Wagen 2004, Abb. 92) and The Netherlands (PÉTREQUIN et al. 2006b, Fig. 6; Koolumans 2006, Figs 7-8).

${ }^{70}$ JEUNESSE 2006, 247, 253, 255.

${ }^{71}$ JOHANNSEN-LAURSEN 2010, 32.

${ }^{72}$ KOREK 1951.

${ }^{73}$ KOREK 1951, 43.

${ }^{74}$ KOREK 1951, 49.

75 BÖKÖNYI 1951, 72-74.

${ }^{76}$ BANNER 1956, 207.

${ }^{77}$ Csalog 1961, 7-10. 
animals deposited together with the humans were dairy cows: each grave contained a cow and a calf, neither of which are yoked to wagons or carts. ${ }^{78}$

I found nothing whatsoever in the description of Grave 3 in the extremely punctilious field diary of the Budakalász cemetery ${ }^{79}$ that would imply that Soproni believed he had found the remains of a genuine wagon, and thus neither can this burial of two humans and two animals be interpreted as representing a wagon burial.

The interment of various animals for ritual or simply health reasons was a widespread practice that is attested in almost every culture from prehistory onward. Regular cattle burials in settlement pits have been found on several sites of the Baden complex and in the northerly regions of Europe during the past decades, suggesting that cattle were one of animals sacrificed during rituals and that in the lack of other conclusive evidence, their interment cannot be associated with wagon burials.

\subsection{A fresh look at the SPR model}

The many advances in archaeometry during the past decades have contributed immensely to archaeology with its new findings (DNA and stable isotope analyses of various animal species, studies on milk protein, etc.). Yet, it must be borne in mind that these analyses and their broader implications were not readily available to archaeologists at the time when Sherratt presented his comprehensive model.

Sherratt's model has been strongly criticised ${ }^{80}$ and refuted in several respects, ${ }^{81}$ principally based on the findings of interdisciplinary analyses, which have revealed that certain elements of Sherratt's SPR model and scenario are no longer tenable and have become outdated on several counts.

Archaeozoologists have refuted the claim that horse was domesticated in the Fertile Crescent, in the cradle of civilisation. On the testimony of the current record, the earliest evidence for domestic horse, dating from the fourth millennium BC, comes from Botai in the Caucasus. Several sites have been investigated in this region as part of archaeological expeditions during the past years, where the high number of recovered domestic horse bones was particularly striking, as was the fact that they differed substantially from the osteology of wild horses, the implication being that these communities had practiced selective horse breeding. ${ }^{82}$ One of the most exciting research issues is the archaeogenetic analysis of horses, which will hopefully contribute to a better understanding of the routes of domestication.

Selective breeding and the exploitation of animal power is attested before the fourth millennium BC. Some one thousand cattle bones came to light at the La Draga settlement in Spain, excavated in 1999, most of which came from 15-24-month-old male individuals and reflected the growing demand for meat in the community. The exploitation of animal traction power at the close of the sixth millennium BC could be demonstrated, although there seems to be no connection with the use of wheeled vehicles. ${ }^{83}$ This site provides the possibly earliest evidence for the use of animal traction power for ploughing.

Biologists analysing milk protein residues surviving on vessel surfaces date the onset of milk consumption well before the fourth millennium BC. In Britain, for example, dairying is attested from the fourth millennium $\mathrm{BC}{ }^{84}$ while in Eastern Europe, evidence for milk production and milk processing is available from the sixth millennium $\mathrm{BC},{ }^{85}$ and from the early seventh millennium $\mathrm{BC}$ in north-western Anatolia, ${ }^{86}$ implying that milk consumption evolved independently of the diffusion of cattle-drawn wheeled vehicles.

Archaeological scholarship now focuses on the "innovation package" of Sherratt's scenario, on the diffusion of the technology of wheeled vehicles. In order to reconstruct the routes of this diffusion, the relevant finds need to be dated as accurately as possible.

\footnotetext{
${ }^{78}$ KOREK 1980, 22.

${ }^{79}$ BONDÁR 2009, 33.

${ }^{80}$ Greenfield et al. 1988; Vosteen 1996; Greenfield 2010; ØSTERGAARD 2011; ARNOLD-GREENFIELD 2015.

${ }^{81}$ MARCINIAK 2011; HodDER 2011; ANTHONY-BROWN 2011.
}

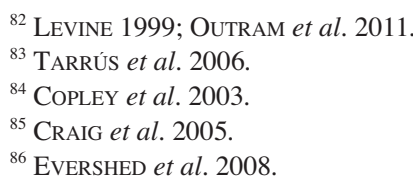




\subsection{Current problems of dating}

In addition to the publication of new finds from various regions, several other issues are now high on archaeological research agendas and a number of previously accepted models have been modified in the light of the new archaeometric findings during the one and a half decades following the study by Lanting and his colleagues, which placed dating on an entirely new footing.

As I have briefly shown in the above, the range of artefacts that can be drawn into research on wheeled conveyances has increased substantially since the beginnings. Familiarity with wheels and wheeled vehicles has been pushed back in time. Wheeled vehicles - miniature wagon models that were earlier interpreted as boat models have been published from the late Tripolye culture of the steppe ${ }^{87}$ It is also clear that wheels cannot be solely associated with wagons or carts, but can equally well be the fixtures of wheeled conveyances for the transportation of produce or wheeled ploughs.

Aside from the wagons found in the elite Mesopotamian burials, genuine wagon burials are also known from the region, ${ }^{88}$ as well as from the steppe (Pit-grave culture) ${ }^{89}$ and the northern Caucasus (Catacomb culture).$^{90}$ The radiocarbon dates for eighteen tumuli of the Pit-grave culture (68\% confidence level) can in part be correlated with the Late Copper Age dates of Central Europe, and in part fall into the Bronze Age. ${ }^{91}$ The calibrated dates for the genuine wagon remains found in burials of the Catacomb culture assign these finds to the Middle Bronze Age, ${ }^{92}$ and thus their comparison with the Late Copper Age finds of the Carpathian Basin calls for caution.

This brings us to the general problem of what can and cannot be compared. Conventional and AMS dates as well as BP and BC dates can only be compared if we are aware of what we are comparing.

The synchronisation of the earlier and the currently accepted chronologies is constrained by several factors. Radiocarbon dates have been made on different types of materials such as carbonates, wood, charcoal, animal and human bones in laboratories with differing equipment. The situation is aggravated by the comparison with dendrochronological dates, the differing periodisation schemes worked out for major regions and individual countries as well as the variety of names given to the same archaeological units and complexes (cultures).

The currently accepted and reliable Accelerator Mass Spectometry (AMS) technology was introduced in 1980. ${ }^{93}$ One of the first AMS laboratories was set up in Arizona in 1981. In Europe, AMS laboratories were established from the mid-1990s. ${ }^{94}$ The comparison of earlier dates and the AMS measurements often yields uncertain results.

Caution must be exercised when comparing dates: we must be aware of whether we are working with $1 \sigma$ and/or $2 \sigma$ ranges, and of which programme is used for calibrating the radiocarbon dates in order to use calendrical years for correlating finds from regions lying far from each other. ${ }^{95}$

Two larger series of radiocarbon dates were published after the article arguing for the rough contemporaneity of the Anatolian and European finds published in $1999 .{ }^{96}$

In 2004, Viktor Trifonov published twenty-two radiocarbon dates for the Maikop culture of the Pontic, which indicated a rough contemporaneity with the Mesopotamian and European finds. ${ }^{97}$ The dates provided by the AMS laboratories of Groningen (Gr), Oxford (OxA) and by the conventional laboratories in Moscow (IGAN) and St. Petersburg (Le $)^{98}$ are given as BP and cal BP, without cal BC values, and thus any comparisons with calendrical years must be treated with caution. In the case of BP dates, it is hardly indifferent whether the date is calculated from 2000, 1950 or the year of the measurement.

\footnotetext{
${ }^{87}$ BONDÁR 2012, 24, with further literature, Fig. 2.1, Fig. 3.

${ }^{88}$ The perhaps best known among these are the royal burials of Ur, whose human remains were recently submitted to scientific analyses (BAADSGAARD et al. 2011).

${ }^{89}$ TuRECKIJ 2004.

${ }^{90}$ BeLINSKIJ-KALMYKOV 2004.

${ }^{91}$ Tureckij 2004, 197, Table 1.

${ }^{92}$ BelinskiJ-KalmyKov 2004b, 215-216.

${ }^{93}$ PAul et al. 1980.

${ }^{94}$ The VERA laboratory in Vienna was established in 1996, the Poznan laboratory in 2001 and the Debrecen laboratory in Acta Archaeologica Academiae Scientiarum Hungaricae 69, 2018
}

2011. The continually updated list of AMS laboratories can be found on the homepage of the journal 'Radiocarbon'.

${ }^{95}$ WENINGER et al. 2015.

${ }^{96}$ BAKKER et al. 1999.

${ }^{97}$ TRIFONOV 2004, Tab. 1.

${ }^{98}$ The laboratory codes are listed on the following home-

pages:

https://www.radiocarbon.org/Info/conventional-labs.htm

https://www.radiocarbon.org/Info/ams-labs.htm. It must here be noted that the Groningen laboratory has several codes in the literature $(\mathrm{Gr}$, GrN and GrA). 
Science-based chronology does not provide secure anchors when comparing the material record of different regions. I have already mentioned some of the pitfalls in the above, to which two other important points must be added.

The earliest evidence for the existence of wheeled vehicles in Anatolia comes from a few pictograms and clay wheel models, which were dated indirectly in a sense, through the finds brought to light from the same contexts: in other words, the date does not relate to the wheeled conveyance itself, but to the finds found in association with it.

In contrast, the radiocarbon or dendrochronological dates can be obtained directly from the wooden finds of Europe. The comparison of these two types of dates is another source of uncertainties. There are many wheel and wheeled vehicle depictions among the petroglyphs of rock art, which span a long period of time. The dating of rock art remains uncertain and essentially relies on indirect evidence.

While modern dating techniques could certainly aid the identification of the chronologically earliest wheeled vehicle, the situation is far from simple, as we have seen.

\subsection{Where were wheeled vehicles invented?}

Even today, secondary school textbooks still maintain that every major invention originated from Mesopotamia, from the cradle of civilisation, a tenet that also dominates public knowledge. Even though finds attesting to the early use of wheeled conveyances have been found in other regions too during the past decades, the axiom of ex oriente lux continues to be firmly rooted in scholarship.

Studies on where wheeled vehicles had been invented now paint a more nuanced picture than the previous model of diffusion from a single centre. In the following, I shall briefly review a few of the many contentions that "things may have happened differently".

Given the many reliable and secure dates, an Anatolian origin and a diffusion from a single centre is no longer tenable.

Maran challenged the Mesopotamian origin of wheeled vehicles already before the publication of the early radiocarbon dates and suggested that wheeled conveyances for transportation had possibly spread southward from the Carpathian Basin. He noted that the prerequisite to resolving this issue was the reliable dating of the wagon models and wagon depictions from the Near East and Greece. In his view, wheeled vehicles spread like wildfire after their invention. ${ }^{99}$

Lanting and his colleagues came to the same conclusion in their article placing the dating of wheeled vehicles on a new foundation. In the light of the new dates, they concluded that wheeled conveyances had either appeared more or less simultaneously in Europe and Mesopotamia, or had spread extremely rapidly from Mesopotamia to Europe. They regarded the latter more probable. ${ }^{100}$

Some scholars believe that the earliest wheeled vehicles appeared in the Pontic. ${ }^{101}$ A polygenetic development has also been postulated, according to which wheeled vehicles had been invented roughly simultaneously in various regions (for example in Europe and Mesopotamia) independently of each other. ${ }^{102}$

In a comprehensive study published a few years ago, Stefan Burmeister discussed the major innovations of the fourth millennium BC, with a special focus on the evidence for wheeled vehicles from Mesopotamia, Northern and Central Europe, the northern Caucasus, Pakistan, the Carpathians and the northern Pontic littoral. His distribution map had twenty-two sites from the period in question. ${ }^{103}$ Various finds indicating a familiarity with, and use of, wheeled vehicles are known from several regions of Europe and Asia between 3500 and 3300 BC. However, current dating methods are still not precise enough and thus these finds appear to be more or less contemporaneous, reflecting either a rapid diffusion from a single centre, or an innovation appearing in several centres, independently of each other. In his view, the issue of the where wheeled vehicles first appeared cannot be resolved using the currently available dating methods. ${ }^{104}$

\footnotetext{
${ }^{99}$ MARAN 1998, 521.

${ }^{100}$ BAKKER et al. 1999, 778.

${ }^{101}$ MATUSCHIK 2006.
}

\author{
102 Vosteen 2006; BondÁR 2012. \\ ${ }^{103}$ Burmeister 2011, Abb. 25. \\ ${ }^{104}$ BURMEISTER 2011, 227. \\ Acta Archaeologica Academiae Scientiarum Hungaricae 69, 2018
}


In contrast to Burmeister, other scholars believe that a "technology transfer" - assuming that wheeled vehicles spread from one centre, for example through trade connections - would only have been possible if there was a social receptiveness to the adoption of the innovation. Evidence for this receptiveness, underpinned by other data, can be cited from several regions. In addition to wheeled vehicles, increasingly more artefacts with a personal association have been identified by more recent research. The research agenda of the Late Copper Age now also includes the identification and interpretation of prestige items, alongside inquiries into personal possessions and issues of the accumulation of wealth and social differentiation. These, in turn, outline certain geographic centres that were more developed than other regions. As demonstrated in the foregoing, the spate of new evidence has greatly undermined the Mesopotamian origin of wheeled vehicles. We can now persuasively posit the existence of communities with a more developed economy during roughly the same period, whose demand for prestige goods and receptiveness to innovations was much stronger than in other cultures.

In 2010, Doris Mischka published thirteen new AMS date for the Flintbek LA 3 site, which gave dates of 3500-3425 cal BC for the eight burials, which thus spanned 75 years, corresponding to three generations. ${ }^{105}$ The dates for the wheel ruts similarly spanned 75 years, falling between 3460 and 3385 cal BC. ${ }^{106}$

In 2011, thirty-two new dates and their Bayesian modelling were published for the Flintbek LA 3 site investigated between 1976 and 1999 (Kiel AMS laboratory, $1 \sigma$ confidence level). These dates indicated that the wheel ruts could be assigned to between 3420 and $3385 \mathrm{cal} \mathrm{BC}$, which in Mischka's view represent the earliest dates for wheeled vehicles in Europe. ${ }^{107}$ She published the earlier dates for wheeled vehicles, specifying the material of the submitted sample, the laboratory where the measurements were performed, the BP and the cal BC dates (but failing to mention their calibration range), as well as the archaeologically estimated age and the source of the date. ${ }^{108}$ She assigned the finds associated with wheeled vehicles to the following groups: scientifically dated genuine vehicles and their depictions (Group A, Sites 1-10), genuine vehicles and their depictions from scientifically dated contexts (Group B1, Sites 11-18), genuine vehicles and their depictions without scientifically dated contexts (Group B2, Sites 19-28) and genuine and assumed wagon models with old dates (Group C, Sites 29-36). Mischka reviewed thirty-nine dates. ${ }^{109}$ The data in her table provide an eloquent illustration of the different materials from which the samples were taken, the calibration (if any), and the need for caution when comparing various categories that are actually unsuitable for comparison. In other words, we cannot really tell at first sight which finds can be actually compared with each other. We need to take account of the accuracy of the measurement and which laboratory it was made in. Even though there has been a welcome increase in the number of available dates, many problems remain regarding the dating of the finds.

I would agree with Burmeister that individual finds still cannot be dated at a finer resolution and to a smaller time interval using the current techniques, making the early finds seem roughly contemporaneous. ${ }^{110}$ Even if we are unable to determine where the very first wheeled vehicle was made, it nevertheless seems quite certain that four-wheeled vehicles appeared in several centres at roughly the same time, even if this means a period of some two hundred years, spanning about seven or eight generations. A polygenetic development seems more likely than a dynamic diffusion from a single centre.

Burmeister and Mischka's studies appeared at roughly the same time as my book, but we were unaware of each other's findings.

I have complemented Mischka's table with the new data and have grouped the early finds from the later fourth and the early third millennium BC slightly differently (Table 1).

A comparison of the European wagon models and the roughly contemporaneous pieces from Iraq, Turkey and Syria reveals that the finds from these two extensive regions differ substantially regarding their form and ornamentation. The exemplars from the Near East are characterised by the clear-cut depiction of the four wheels, with the wheels set on prominent axles. They are generally adorned with an incised herringbone or zig-zag pattern. In contrast to the European wagon models, these pieces can be seen as either forerunners of the later battle chariots or as miniatures of covered wagons. ${ }^{111}$ The European pieces depict vehicles with a rectangular, open wagon

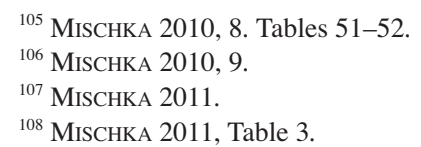

\footnotetext{
${ }^{109}$ Table 3, the supplement to the article published in 'Antiquity', can be accessed at http://antiquity.ac.uk/projgall/mischka329/

${ }^{110}$ BURMEISTER 2011, 240.

${ }^{111}$ BONDÁr 2004, Figs 9-14; BONDÁR 2012, Fig. 15.1,3-4
} 
box, ${ }^{112}$ In view of the many dissimilarities, we may reasonably ask whether a genetic link can indeed be assumed between the European and Near Eastern wagons. ${ }^{113}$

It seems to me that the most likely scenario is that the invention of the wheel and the associated vehicle occurred in several regions of Eurasia at roughly the same time.

The distribution of the securely dated early finds from the later fourth millennium BC outlines a number of centres where different find assemblages attest to a familiarity with, and use of, wheels and wheeled conveyances.

The inventory from Mesopotamia (Iraq, Syria and Turkey in the broader sense) includes pictograms, vehicles on stone reliefs, clay wheel models and mostly metal vehicle models as well as cast metal figurines of draught animals.

The Caucasus is characterised by genuine wagon burials and the occasional clay wheel model, while clay wagon models and wooden wheels have been reported from the Pontic region (Ukraine).

Pictograms incised onto vessels, miniature clay wheels and clay figurines portraying yoked animals are known from Northern Europe (Poland).

The find material from Western Europe (Switzerland, Germany, The Netherlands, Denmark and France) and Croatia attesting to a familiarity with wheels and the use of wheeled vehicles is made up of genuine wooden wheels, axles and conveyances for the transportation of produce preserved in wetland environments as well as wheel ruts and timber trackways. Some sites have also yielded miniature clay wheels and animal figurines.

Few finds have been published from South-East Europe (Greece and Italy). The early relics of wheels, wagons, wheeled transportation and ploughing have been preserved by rock art depictions, while in the case of Greece we can cite the wagon model from the renowned Palaikastro site.

The relevant material from the central regions of Europe (Austria, Hungary, Czech Republic, Slovakia and Romania) comprises miniature clay wagons and small wheels, clay protomes and clay animal figurines.

Eleven of the eighteen miniature wagon models of the Late Copper Age in the Carpathian Basin were found in Hungary. ${ }^{114}$ If we add to these the small wheel models, the wooden fixtures of genuine wheeled vehicles and the timber trackways as well as the growing number of rock art depictions, it seems that one of the early centres where wheeled vehicles appeared was the heartland of Europe.

\section{CONCLUSION}

The invention of the wheel and of wheeled vehicles sparked a number of social and economic processes in the fourth millennium BC that had an impact on the organisation of and interaction between the period's communities and also profoundly transformed the hierarchy between individual settlements.

The more widespread use of wheeled vehicles called for the construction of roads which, on the testimony of the archaeological record, were indispensable in mountain areas where wheeled vehicles could only navigate the rugged, muddy terrain if roads or short stretches of roadways were constructed of timber. This called for felling trees, de-limbing them and then fitting together the logs using the period's tools. Tree felling and the construction of roads is an indication of the division of labour within communities and it also called for coordination, organisation and specialist knowledge for choosing the appropriate timber type for the road as well as of the necessary construction techniques.

The roads withstanding the effects of weather that also passed through mountains opened a range of new possibilities for trade and communication, and led to the emergence of the routes of regular exchanges. Distance was no longer an insurmountable obstacle and down-the-line trade meant that countless commodities became available within a reasonable time. This unrivalled innovation also promoted the broadening of information exchange and cultural contacts between distant communities. Our ancestors were capable of reaching far more distant lands and of gaining information about the natural endowments of faraway regions and about the lifeways, customs and beliefs of their inhabitants. In addition to gaining information, new human relations were inevitably forged too (friendships, marriages, relocations, etc.).

\footnotetext{
${ }^{112}$ BONDÁR 2012, Figs 5-14, Fig. 15.2, Fig. 16.

${ }^{113}$ BONDÁR 2004, 27; BONDÁR 2012, 91.
}

\footnotetext{
${ }^{114}$ BONDÁR 2012, Fig. 19.
}

Acta Archaeologica Academiae Scientiarum Hungaricae 69, 2018 
Among the Late Copper Age innovations, the appearance of the wheel and wheeled vehicles launched an "industrial revolution". Late Copper Age inventions and innovations precipitated other discoveries that have remained with us until the present. These innovations had a positive impact on the life of the period's communities. Better life circumstances led to rudimentary forms of wealth accumulation (wealth and prestige items) and social differentiation became more visible as it was also embodied by these commodities. At first, wheeled vehicles were the prerogative of the elite and only later did they become a genuine medium of communication and transportation.

Based on the distribution of wheeled vehicles and the prestige items appearing simultaneously, it would appear that aside from Mesopotamia, developed communities with the necessary needs, economic position and social receptiveness that were capable of coming up with new innovations and inventions or of integrating these into their lives could be found in the southern Ukraine (late Tripolye culture), the Caucasus (Maikop culture) and in Central Europe (Baden complex) in the mid-fourth millennium BC.

Without the curiosity, ingenuity and perseverance of our Late Copper Age ancestors, we would have neither hybrid and solar-powered cars, nor modern agricultural machinery. Their innovations were conceived during a long time, but had a lasting impact. As we have seen, the wheels, carts and wagons they invented five and half thousand years ago have withstood the test of time. The rational and many-sided exploitation of animals has not faded and some technologies have survived in an unchanged form. However, the function and ritual role of wheeled vehicles has been transformed - they have transitioned from the ritual to the profane, from prestige items to being a mass commodity, often instrumental to work, although their luxury nature has also persisted to some extent.

The goal of this study was to show how our perception of the wheel and of wheeled conveyances, one of the outstanding Late Copper Age innovations, and their many aspects have changed since the publication of the first overviews up to the present.

It was also my intention to demonstrate how an inquiry into a more unusual artefact type can bring to light pieces of the mosaic of complex historical and economic processes, and how a complex research matrix and interdisciplinary cooperation can contribute to interpreting the pieces of the mosaic we find and how we can illuminate many hidden aspects of ancient life. 


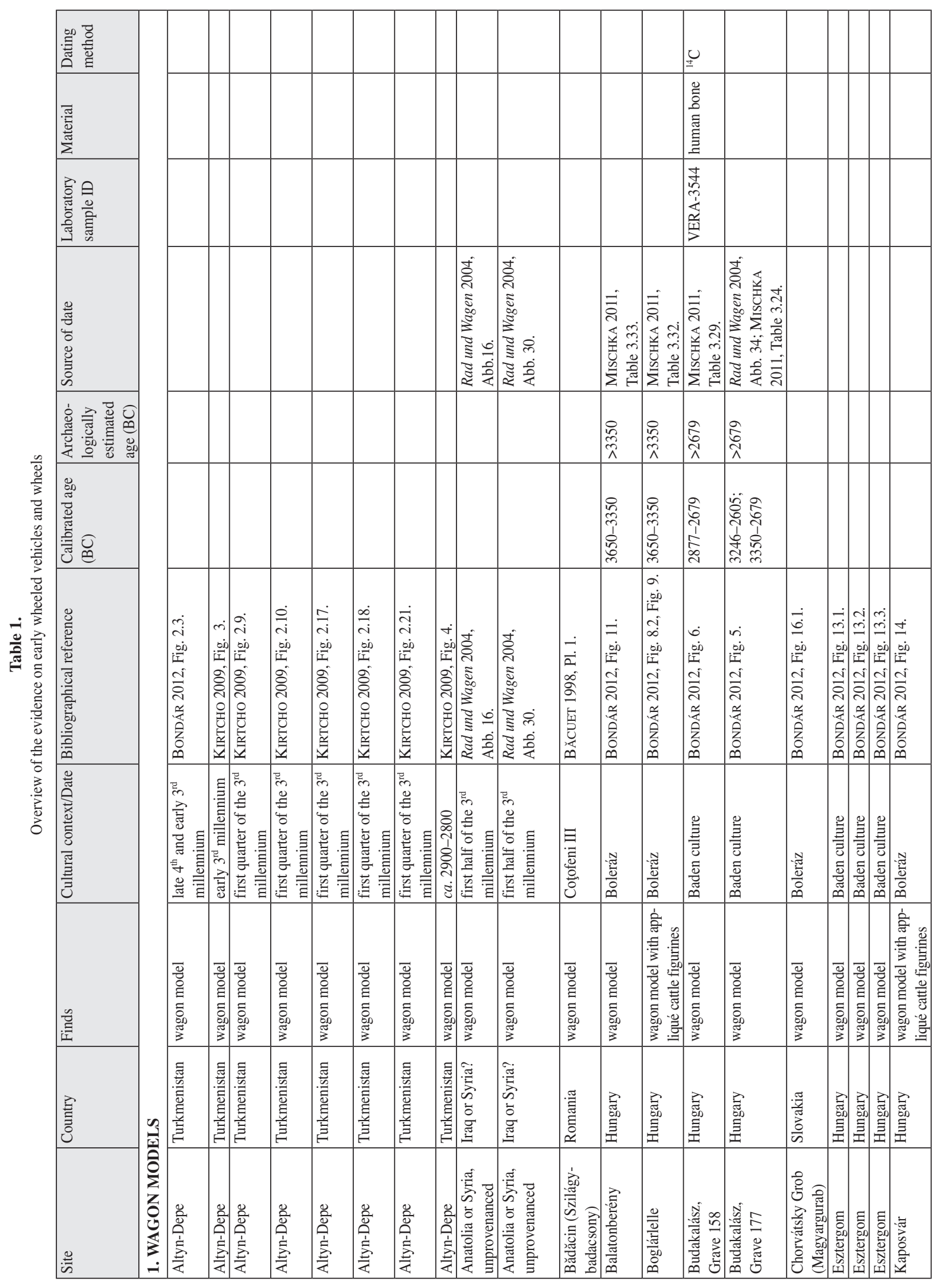




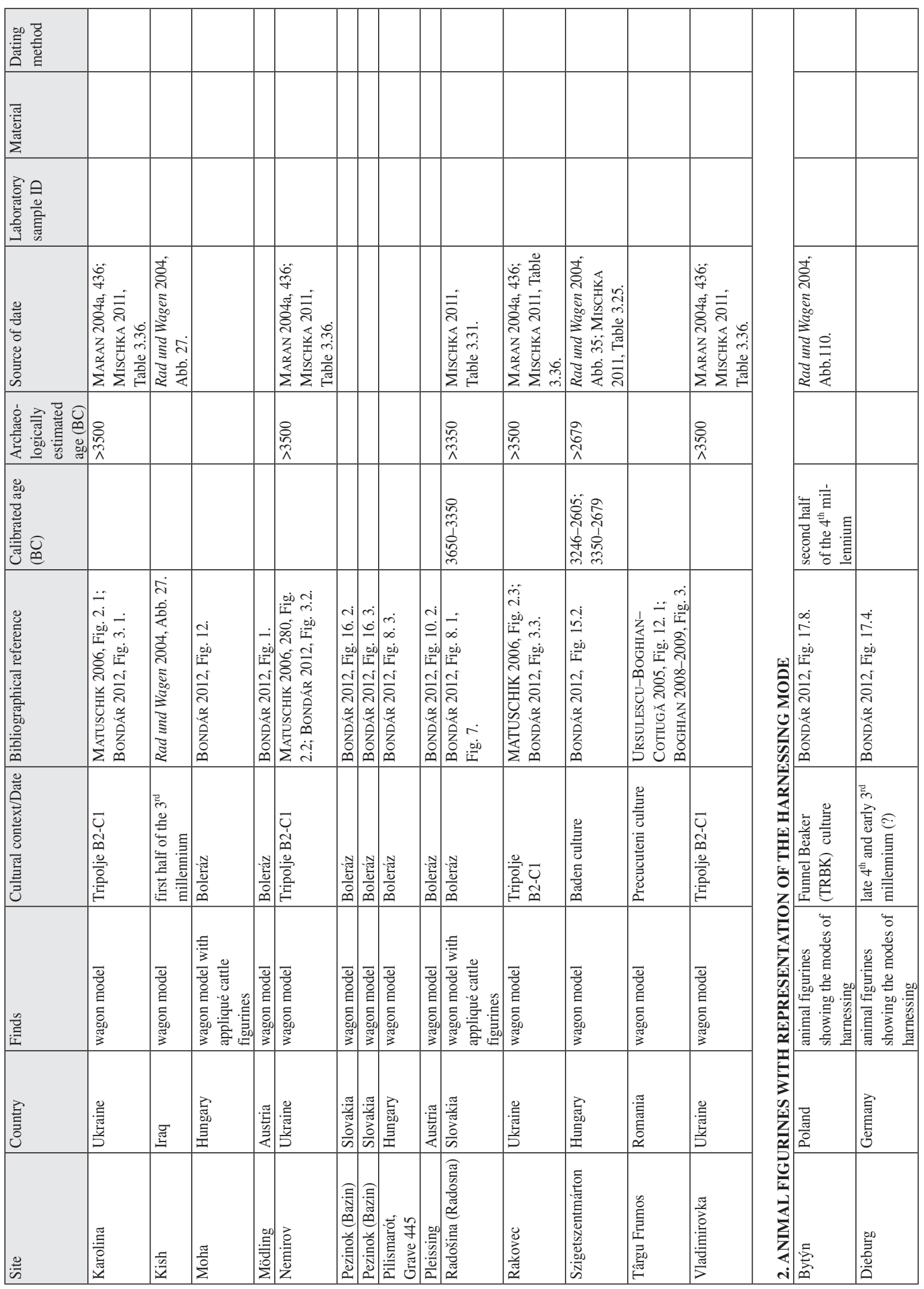




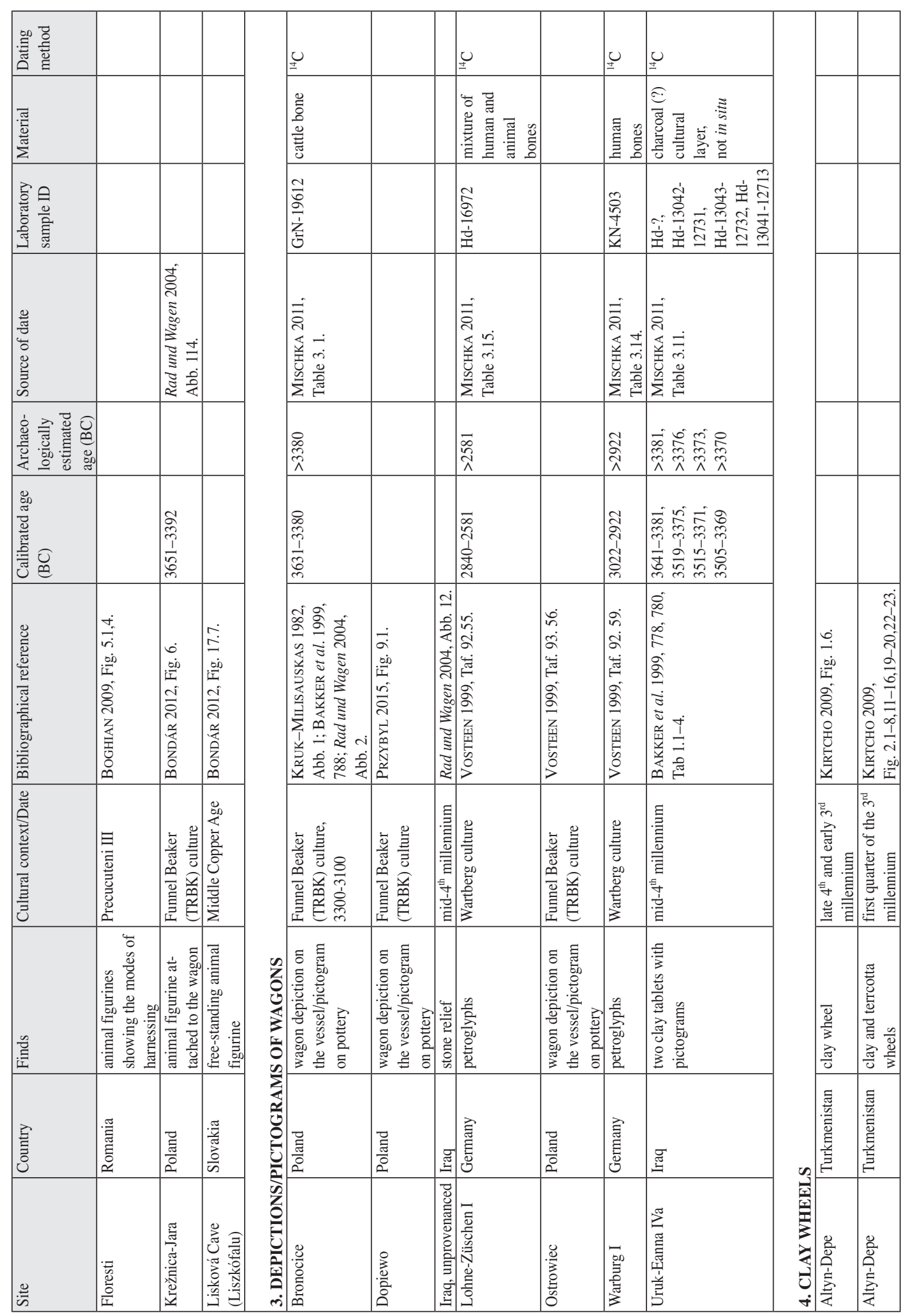




\begin{tabular}{|c|c|c|c|c|c|c|c|c|c|c|c|c|c|c|c|c|c|}
\hline 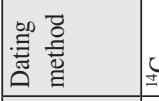 & ب & & & & & & & & & & & & \pm & & & & \\
\hline 氶 & 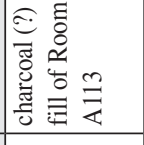 & & & & & & & & & & & & 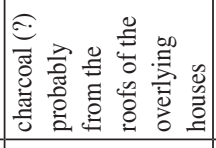 & & & & \\
\hline 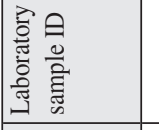 & & & & & & & & & & & & & 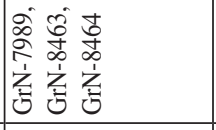 & & & & \\
\hline 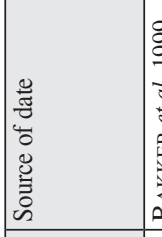 & 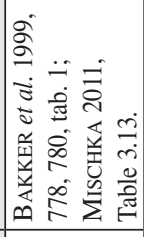 & & & & & 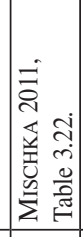 & & & & & & & 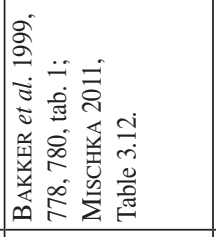 & & 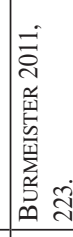 & & 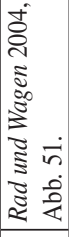 \\
\hline 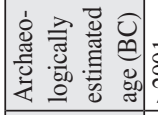 & 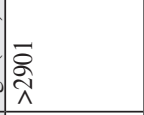 & & & & & 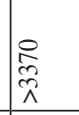 & & & & & & & 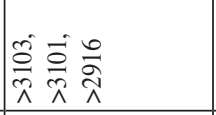 & & & & \\
\hline 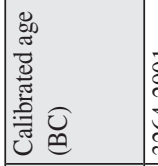 & 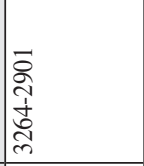 & & & & & & & & & & & & 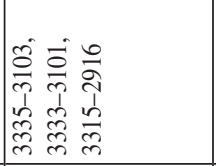 & & 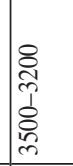 & & \\
\hline 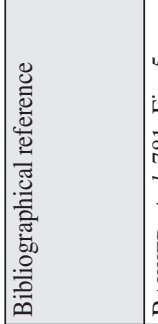 & 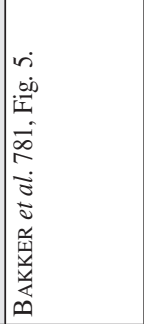 & 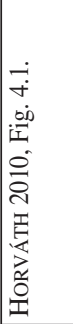 & 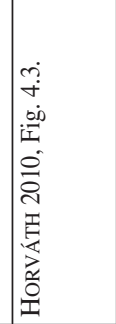 & 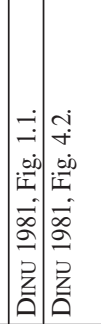 & 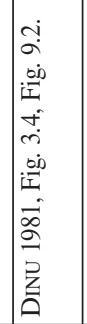 & 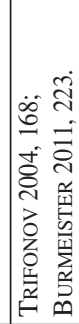 & 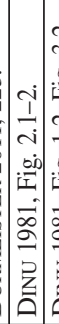 & & 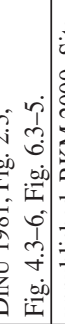 & 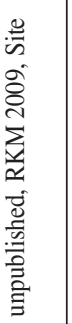 & 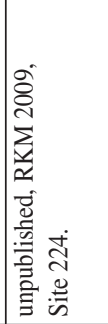 & 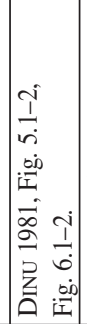 & 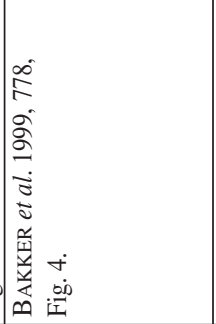 & 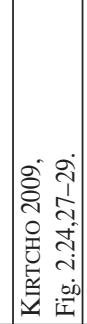 & 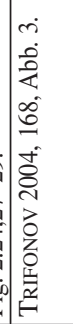 & 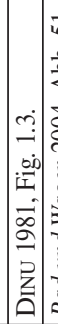 & 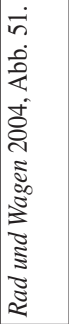 \\
\hline 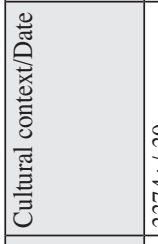 & 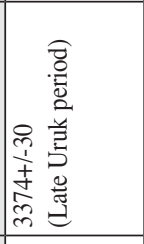 & 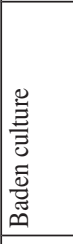 & 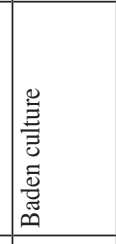 & 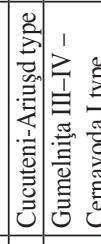 & 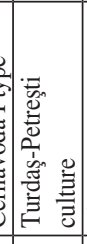 & 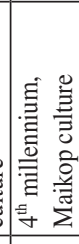 & 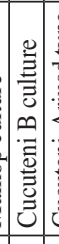 & \begin{tabular}{l|l} 
\\
0 \\
0
\end{tabular} & 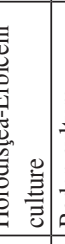 & 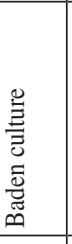 & 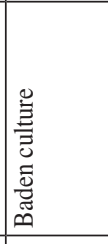 & 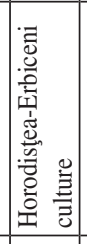 & 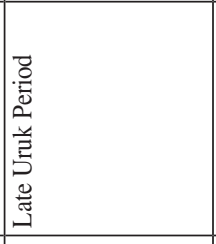 & 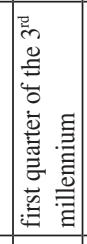 & 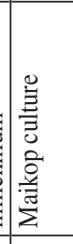 & 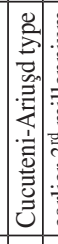 & 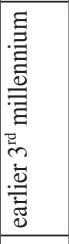 \\
\hline 总 & 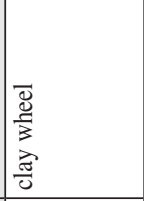 & 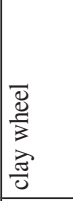 & $\begin{array}{l}\bar{\Xi} \\
\frac{\pi}{3} \\
\frac{\mathbb{E}}{0} \\
\end{array}$ & 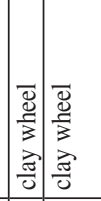 & 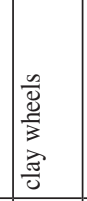 & 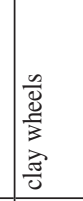 & 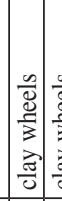 & & & 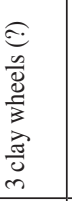 & 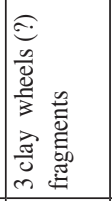 & 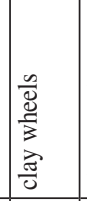 & 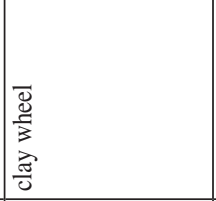 & 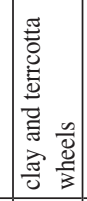 & $\begin{array}{ll}\frac{n}{2} \\
\frac{2}{2} \\
\frac{2}{3} \\
\frac{\pi}{0} \\
\end{array}$ & 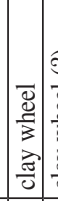 & 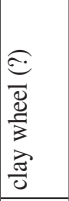 \\
\hline 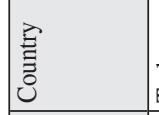 & 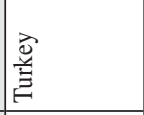 & 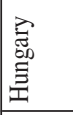 & 㤐 & 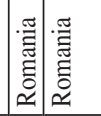 & 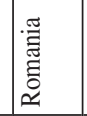 & 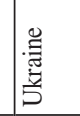 & 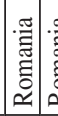 & & & 窝 & 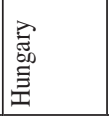 & 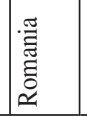 & 祢 & | & 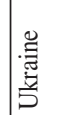 & & 商 \\
\hline . & 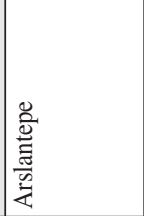 & 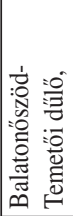 & 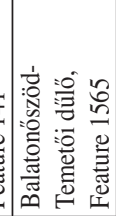 & 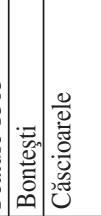 & 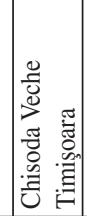 & : & 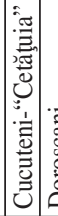 & & & 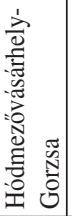 & 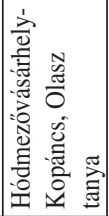 & 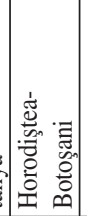 & 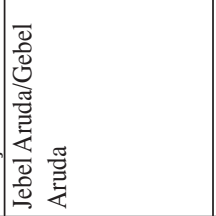 & 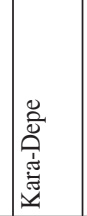 & 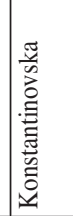 & 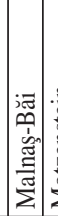 & 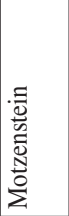 \\
\hline
\end{tabular}




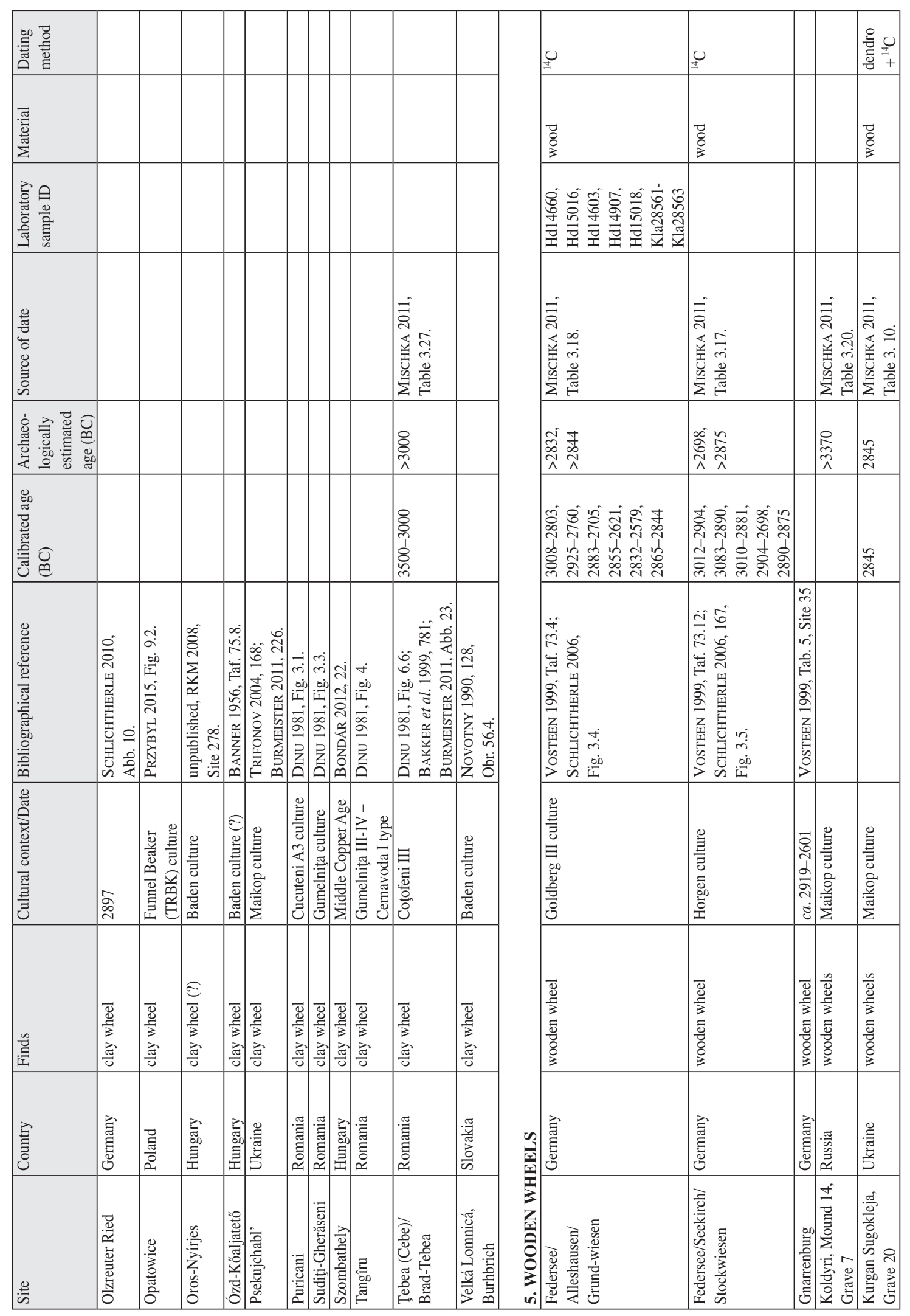




\begin{tabular}{|c|c|c|c|c|c|c|c|c|c|c|}
\hline 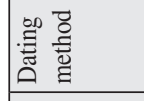 & ب & & 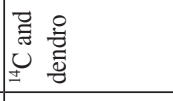 & $\frac{}{\frac{g}{g}}$ & & & & ૫ & & \\
\hline 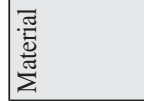 & \begin{tabular}{|l}
$\overrightarrow{0}$ \\
$\vdots$ \\
\end{tabular} & & ت्ञ & 总 & & & & $\begin{array}{l}\overline{0} \\
\vdots \\
\vdots\end{array}$ & & \\
\hline 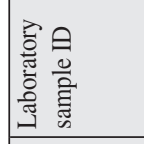 & 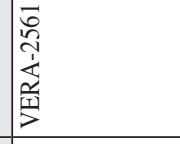 & & 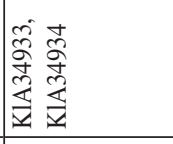 & & & & & & & \\
\hline 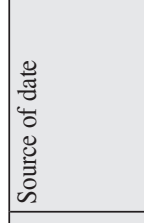 & 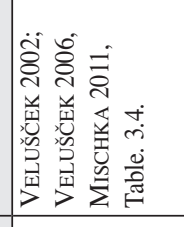 & 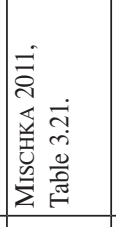 & 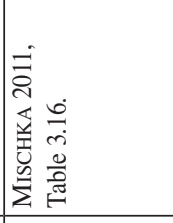 & 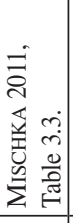 & 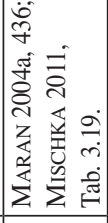 & & & 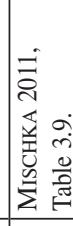 & 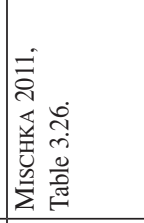 & \\
\hline 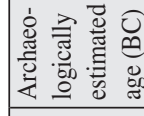 & 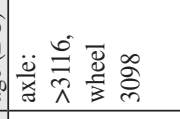 & 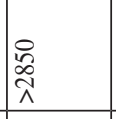 & 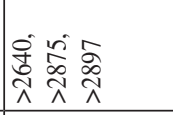 & ๙ૂ & 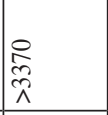 & & & $\begin{array}{l}\infty \\
\infty \\
\infty \\
\end{array}$ & 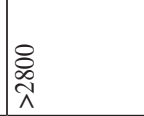 & \\
\hline 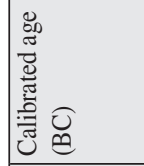 & 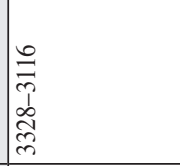 & & 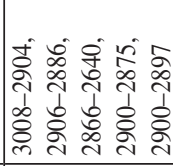 & חิ & & & & 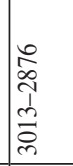 & 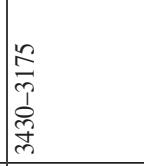 & \\
\hline 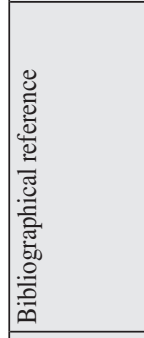 & 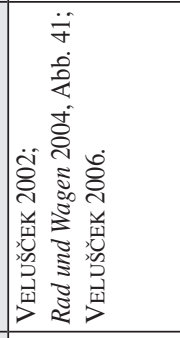 & 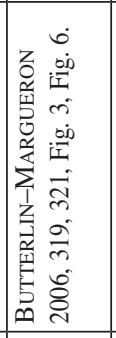 & 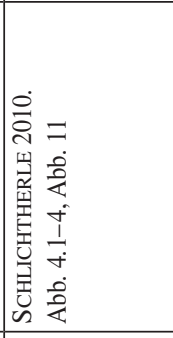 & 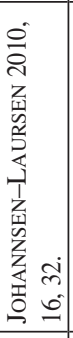 & & 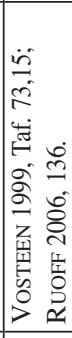 & 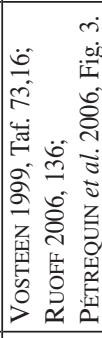 & 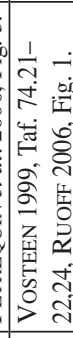 & 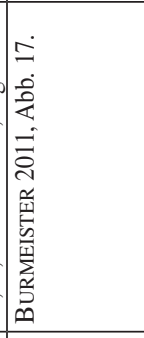 & 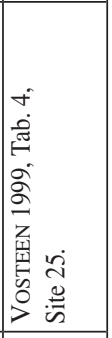 \\
\hline 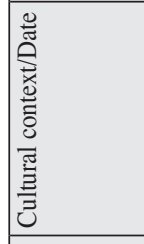 & 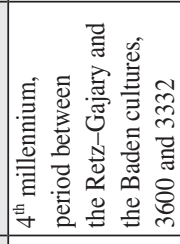 & 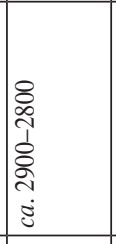 & 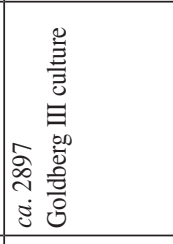 & 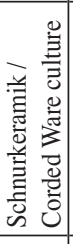 & 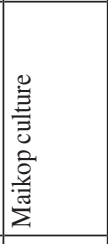 & 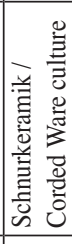 & 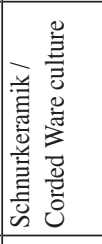 & 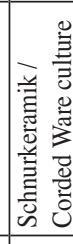 & 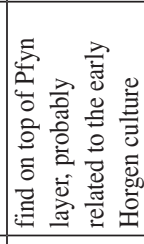 & 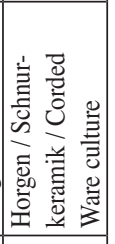 \\
\hline 曾 & 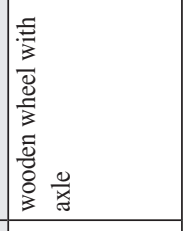 & 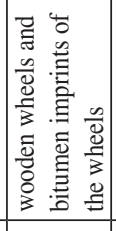 & 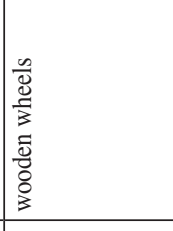 & 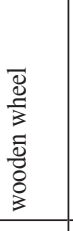 & 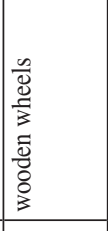 & 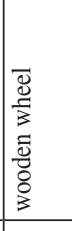 & 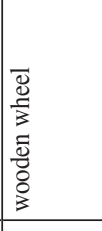 & 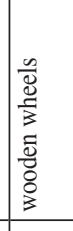 & 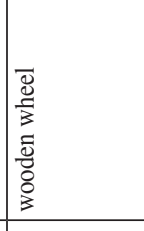 & 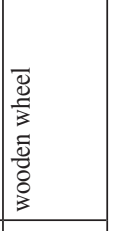 \\
\hline ठे & 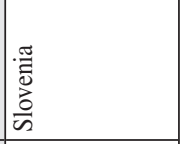 & 䮈 & 产 & 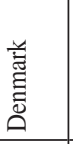 & 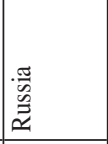 & 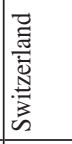 & 胥 & 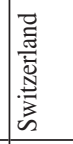 & 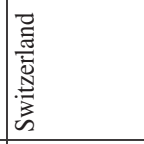 & 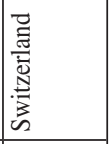 \\
\hline 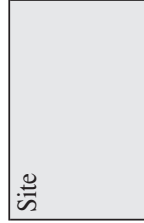 & 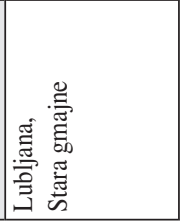 & 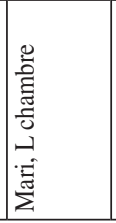 & 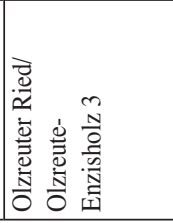 & \begin{tabular}{l} 
品 \\
产 \\
\multirow{2}{*}{}
\end{tabular} & 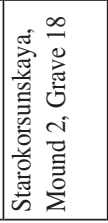 & 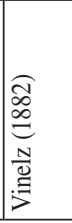 & 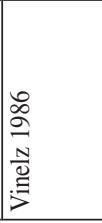 & 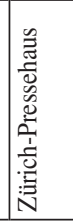 & 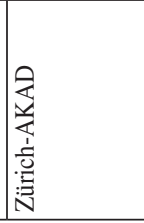 & 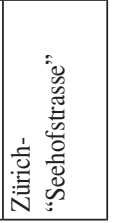 \\
\hline
\end{tabular}




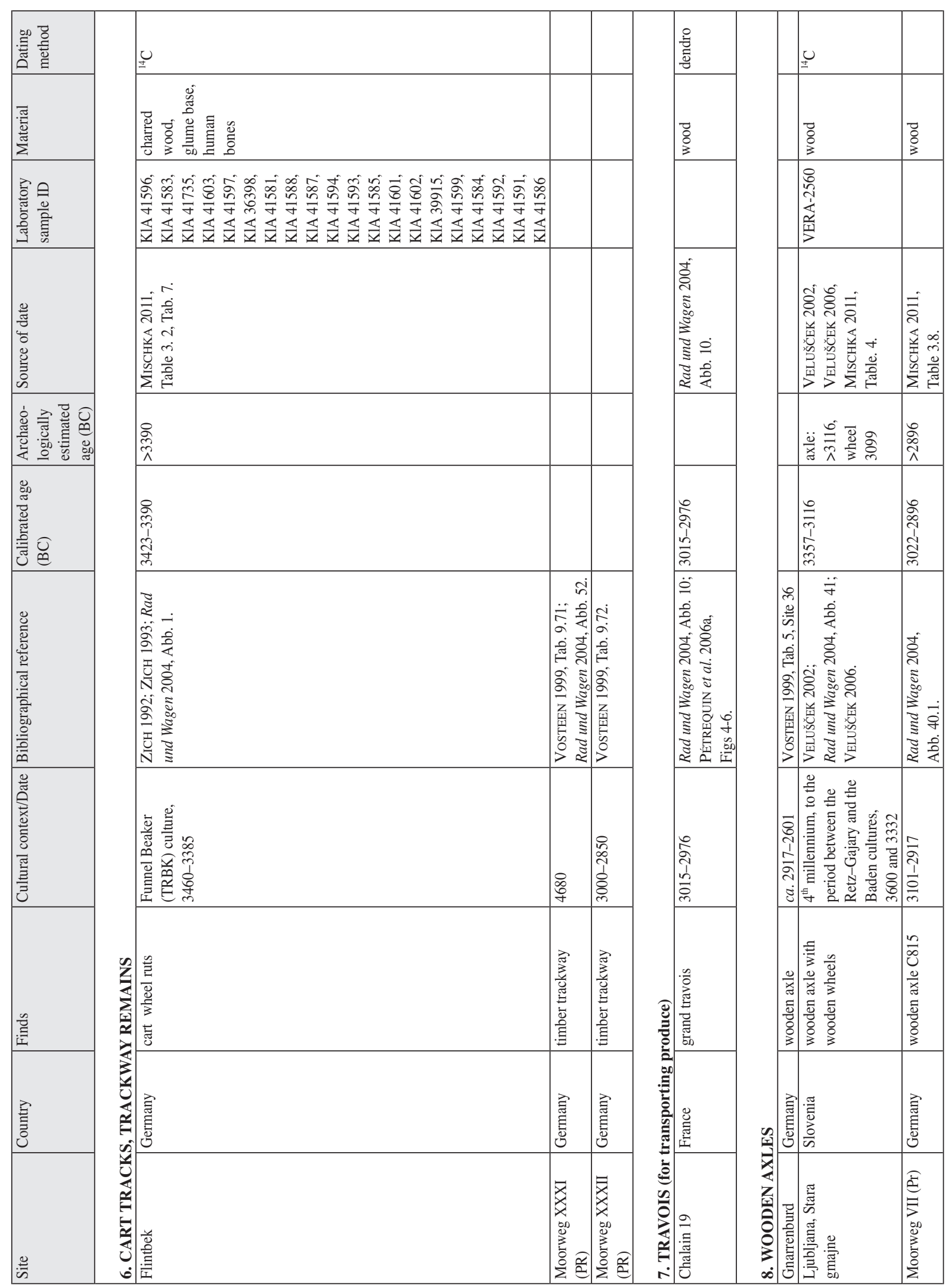




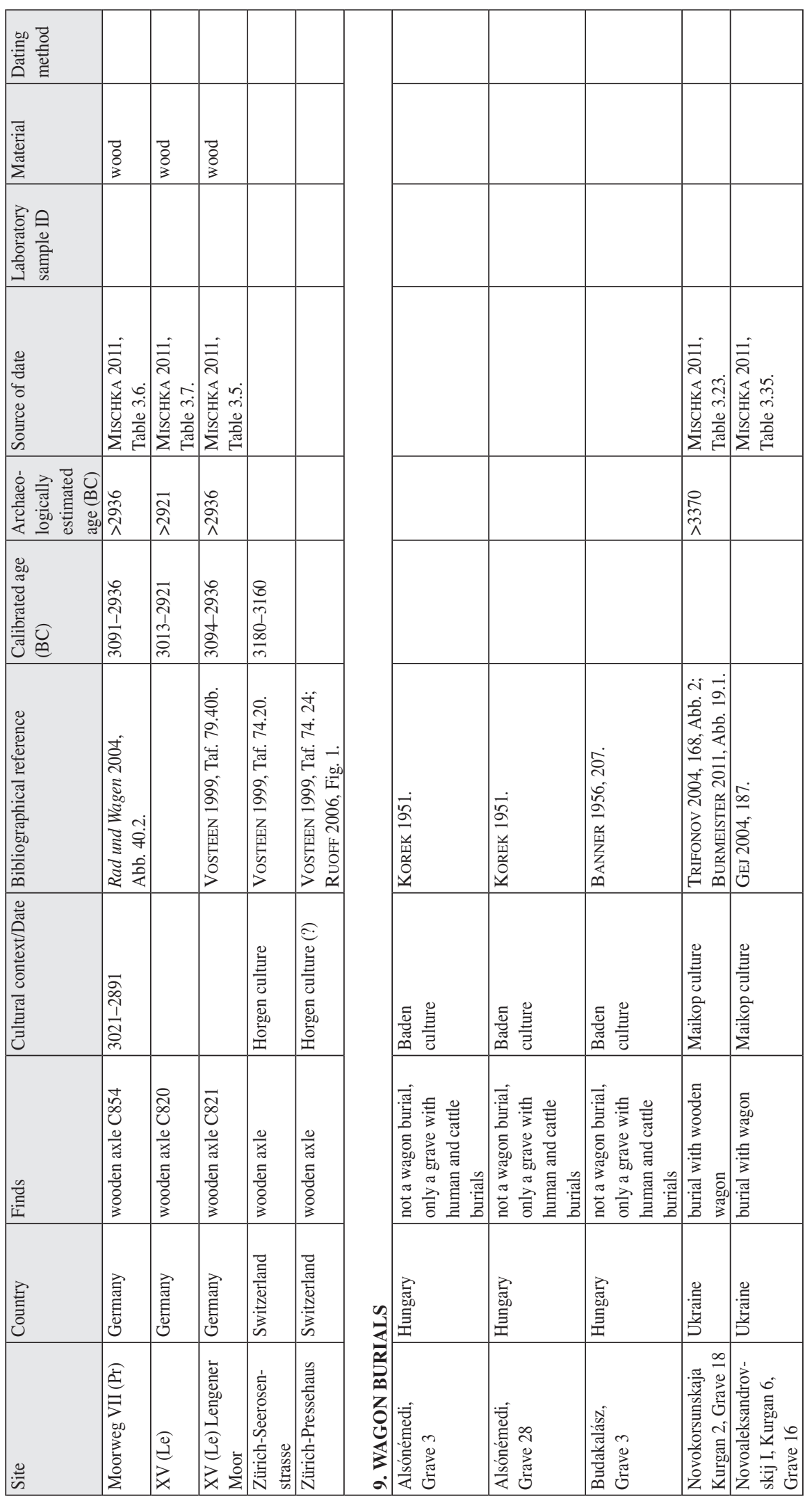

Acta Archaeologica Academiae Scientiarum Hungaricae 69, 2018 
REFERENCES

ANATI 1960

ANATI 2014

ANTHONY 1990

ANTHONY 1995

ANTHONY 2007

ANTHONY 2008

ANTHONY-BROWN 2011

ANTHONY-VINOGRADOV 1995

ARNOLD-GREENFIELD 2015

BAADSGAARD et al. 2011

BACUET 1998

BAKKER et al. 1999

BANNER 1956

BELINSKIJ-KALMYKOV 2004

Between the Aegean

and Baltic Seas 2007

BOGHIAN 2009

BONDÁR 2004

BONDÁR 2006

BONDÁR 2009

BONDÁR 2012

BONDÁR-SZÉKELY 2011

BÓNA 1960

BÓNA 1992

BOROFFKA 2004

BÖKÖNYI 1951

BURMEISTER 2004

BURMEISTER 2006

BURMEISTER 2011
= E. ANATI: Bronze Age chariots from Europe. PPS 26 (1960) 50-62.

$=$ E. ANATI: Valcamonica rock art: State of the art. BCSP 37-38 (2014) 7-18.

= D. W. Anthony: The Baby and the Bathwater. AmAn New Ser. 92 (1990) 895-914.

= D. W. Anthony: Horse, wagon and chariot: Indo-European languages and archaeology. Antiquity 69 (1995) 554-565.

= D. W. Anthony: The Horse, the Wheel and Language: How Bronze-Age Riders from the Eurasian Steppes Shaped the Modern World. Princeton University Press, Princeton, NJ 2007.

= D. W. Anthony: A new approach to language and archaeology: The Usatovo culture and the separation of Pre-Germanic. JIES 36 (2008) 2-51.

= D. W. ANTHONY-D. BRown: The secondary products revolution: Horse-riding and mountened warfare. JWP 24 (2011) 131-160.

= D. W. Anthony-N. B. Vinogradov: Birth of the chariot. Excavations east of the Ural Mountains reveal traces of the first two-wheeled high-performance vehicles. Archaeology 48 (1995) 36-41.

= E. R. ARNOLD-H. J. GREENFIELD: 'Go(a)t milk?' New perspectives on the zooarchaeological evidence for the earliest intensification of dairying in south eastern Europe. WA 14 April 2015. Published on-line

= A. BAADSGaARD-J. Monge-S. CoX-R. L. ZetTleR: Human sacrifice and intentional corpse preservation in the Royal Cemetery of Ur. Antiquity 85 (2011) 27-42.

= S. BACUET: Un cărucior de lut descoperitla Bădăcin (Jud. Sălaj) (A clay wagon discovered at Bădăcin, Sălaj County). Apulum 35 (1998) 37-41.

= J. A. BAKKER-J. KRUK-A. E. LANTING-S. MilisAuskas: The earliest evidence of wheeled vehicles in Europe and the Near East. Antiquity 73 (1999) 778-790.

= J. BANNER: Die Péceler Kultur. ArchHung 35. Akadémia Kiadó, Budapest 1956.

= A. B. BelinskiJ-A. B. KalmyKov: Neue Wagenfunde aus Gräbern der Katakombengrab-Kultur im Steppengebiet des zentralen Vorkaukasus. In: FANSA-BURMEISTER (eds) 2004b, 201-220.

= I. GalanaKis-H. Tomas-Y. GalanaKis-R. LAFFineur (eds): Between the Aegean and Baltic Seas. Prehistory across borders. Proceedings of the International Conference. "Bronze and Early Iron Age Interconnections and Contemporary Developments between the Aegean and the Regions of the Balkan Peninsula, Central and Northern Europe", University of Zagreb, 11-14 April 2005. Aegeum 27. Liège 2007.

= D. D. Boghian: Cu privire la unele vase eneolitice cu protome perechi (Considérations sur les quelques vases énéolithiques avec protomés paires). MemAnt 25-26 (2008-2009) 159-170.

= M. BondÁR: A kocsi a késő rézkori Európában (Der Wagen im spätkupferzeitlichen Europa). ArchÉrt 129 (2004) 5-34.

= M. BondÁR: Le chariot en Europe au Chalcolithique récent. In: PÉTREQUIN et al. (eds) 2006, 225 237.

= M. Bondár: The Cemetery. In: The Copper Age Cemetery of Budakalász. Eds: M. Bondár, P. Raczky. Budapest 2009, 11-302.

= M. BondÁR: Prehistoric Wagon Models in the Carpathian Basin (3500-1500 BC). Archaeolingua SerMinor 32. Budapest 2012.

= M. BondáR-Gy. V. SzÉkely: A New Early Bronze Age Wagon Model from the Carpathian Basin. WA 43 (2011) 538-553.

= I. BónA: Clay models of Bronze Age wagons and wheels in the Middle Danube Basin. ActaArchHung 12 (1960) 83-111.

$=$ I. BónA: Wagen und Wagenmodelle in der Tell-Kulturen. In: Bronzezeit in Ungarn. Forschungen in Tell Siedlungen an Donau und Theiss. Ausstellungskatalog. Ed.: I. Bóna. Museum für Vor- und Frühgeschichte. Frankfurt am Main 1992, 73-75.

$=$ N. BOROFFKA: Nutzung der tierischen Kraft und Entwicklung der Anschirrung. In: FANSABURMEISTER (eds) 2004b, 467-480.

$=\mathrm{S}$. BÖKÖNYI: Untersuchung der Haustierfunde aus dem Gräberfeld von Alsónémedi. ActaArchHung 1 (1951) 72-79.

$=\mathrm{S}$. BuRMEISTER: Der Wagen im Neolithikum und in der Bronzezeit: Erfindung, Ausbreitung und Funktion der ersten Fahrzeuge. In: FANSA-BURMEISTER (eds) 2004b, 13-40.

= S. BurmeIster: Chemins néolithiques in Allemagne du Nord. In: PÉTreQuin et al. (eds) 2006 , 207-214.

$=\mathrm{S}$. BurmeISTER: Innovationswege - Wege der Kommunikation. Erkenntnissprobleme und Beispiel des Wagens im 4. Jt. v. Chr. In: Sozialarchäologische perspektiven: gesellschaftliche Wandel 50001500 v. Chr. zwischen Atlantik und Kaukasus. Internationale Tagung 15.-18. Oktober 2007 in Kiel. 
BUTTERLIN-MARGUERON 2006

ChILde 1951

ChILde 1954

Copley et al. 2003

CRAIG et al. 2005

CsALOG 1961

DRENTH-BAKKER 2006

EVERSHED et al. 2008

FANSA-BURMEISTER (eds) 2004a

FANSA-BURMEISTER (eds) 2004b

FEDELE 2006

FELdMAN-SAUVAGE 2010

FORNI 1988

GAUTHIER-GAUTHIER 2011

GEJ 2004

GREENBERG 2014

GREENFIELD et al. 1988

GREENFIELD 2010

HÄUSLER 1978

HÄUSLER 1981

HÄUSLER 1984

HÄUSLER 1985

HÄUSLER 1986

HÄUSLER 1992

HoDDER 2011

HoRVÁth 2010
Hrsg.: S. Hansen, J. Müller. Archäologie in Eurasien 24. Darmstadt: Philippe von Zabern 2011, 211-240.

= P. Butterlin-J-C. Margueron: Deux roues à Mari et le problème de l'invention de la roue en Mésopotamie. In: PÉTREQuIN et al. (eds) 2006, 317-328.

= G. V. CHILDE: The first waggons and carts from the Tigris to the Severn. PPS 17 (1951) 177-194.

= G. V. CHILDE: The diffusion of wheeled vehicles. EAZ 2 (1954) 1-17.

= M. S. Copley-R. Berstan-S. N. Dudd-G. Docherty-A. J. MukherjeE-V. Straker-S. PayneR. P. EVERSHED: Direct chemical evidence for widespread dairying in prehistoric Britain. Proceedings of National Academy of Science USA 100 (2003) 1524-1529.

= O. E. Craig-J. Chapman-C. Heron-L. H. Willis-L. Bartosiewicz-G. TAYlor-A. Whittle: Did the first farmers of Central and Eastern Europe produce dairy foods? Antiquity 79 (2005) 882-894.

= J. CsALOG: Adatok a bádeni (péceli) nép kocsitemetkezéseihez és életformájának kérdéséhez (Data to the waggon burials and the ways of life of the Baden (Pécel) folk). ArchÉrt 88 (1961) 7-22.

= E. DRENTH-J. A. BAKKer: Im memoriam Albert Lanting. 10 April 1941-13 December 2004. Palaeohistoria 47-48 (2005-2006) 3-37.

= R. P. Evershed-S. Payne-A. G. Sherratt-M. S. Copley-J. Coolidge-D. Urem-KotsuK. Kotsakis-M. ÖZdoĞAn-A. E. ÖZdoĞAn-O. Nieuwenhuyse-P. M. AKKermanns-D. BaileyR. R. Andreescu-S. CAMPBEll-S. FArid-I. Hodder-N. YAlman-M. ÖZBAŞARAN-E. BiçAKCIY. GARFINKEL-T. LEVY-M. M. Burton: Earliest date for milk use in the Near East and southeastern Europe linked to cattle herding. Nature 455 (2008) 528-531.

$=$ Rad und Wagen. Der Ursprung einer Innovation; Wagen im Vorderen Orient und Europa. Sonderausstellung. Landesmuseum für Natur und Mensch Oldenburg vom 28. März bis 11. Juli 2004. Konzept: S. Burmeister und M. Fansa. Führer durch die Ausstellung. Isensee Verlag. Beiheft der Archäologische Mitteilungen aus Nordwestdeutschland 40. Oldenburg 2004.

= M. FAnsa- S. Burmeister (Hrsg.): Rad und Wagen. Der Ursprung einer Innovation; Wagen im Vorderen Orient und Europa. Austellung vom 28. März bis 11. Juli 2004. Wissenschaftliche Begleitschrift zur Sonderausstellung. Verlag Philipp von Zabern. Mainz am Rhein 2004.

$=$ F. FEDELE: La traction animale au Val Camonica et en Valteline pendant le néolthique et le Chalcolithique (Italie). In: PÉTREQUin et al. (eds) 2006, 47-61.

$=$ M. H. Feldman-C. SAuvage: Objects of prestige? Chariots in the Late Bronze Age Eastern Mediterranean and Near East. Agypten und Levant/Egypt and the Levant 20 (2010) 67-181.

= G. FORNI: Origini e storia dell'aratro e del carro in Padania. In: Gli strumenti di lavoro tradizionali lodigiana e loro storia. Eds: G. Bassi, G. Firni. Museo Lombardo di Storia dell'Agricoltura. Milano 1988, 5-56.

= Y. GAUTHIER-C. GAUTHIER: Des chars et des Tifinagh: étude aréale te corrélations. Cahiers de l'Amis des Art Rupestre Saharien (AARS) 15 (2011) 91-118.

= A. N. GEJ: Die Wagen der Novotitarovskaja-Kultur. In: FANSA-BuRMEISTER (eds) 2004b, 177-190.

$=$ R. GreEnberg: Ox-carts the Kura-Araxes migrations. In: Problems of Early Metal Age Archaeology of Caucasus and Anatolia. Proceedings of International Conference November 19-23, 2014. Ed.: G. Narimanishvili. Georgia, Tbilisi 2014, 94-101.

= H. J. Greenfield-J. Chapman-A. T. Clason-A. S. Gilbert-B. Hesse-S. Milisauskas: The origins of milk and wool production in the Old World: A zooarchaeological perspective from the Central Balkans [and comments]. CurrAnt 29 (1988) 573-593.

$=$ H. J. GREENFIELD: The secondary products revolution: the past, the present and the future. WA 42 (2010) 29-54.

= A. HÄUSLER: Migration oder autochtone Entwicklung? EAZ 19 (1978) 243-256.

= A. HÄUSLER: Zu ältesten Geschichte von Rad und Wagen im nordpontischen Raum. EAZ 22 (1981) 581-647.

= A. HäUSLER: Neue Belege zur Geschichte von Rad und Wagen im nordpontischen Raum. EAZ 24 (1984) 629-668.

= A. HÄUSLER: Die Anfänge von Rad und Wagen in der Kulturgeschichte Europas. In: Produktivkräfte und Produktionsverhältnisse. Hrsg.: F. Horst, B. Krüger. Academie Verlag, Berlin 1985, 121-133.

= A. HÄUSLER: Rad und Wagen zwischen Europa und Asien. In: Achse, Rad und Wagen. Fünftausende Jahre Kultur- und Technikgeschichte. Hrsg.: W. Treue. Vandenhoeck and Ruprecht, Göttingen 1986, $140-154$.

= A. HÄUSLER: Der Urspung des Wagens in der Diskussion der Gegenwart. Archäologische Mitteilungen aus Nordwestdeutschland 15 (1992) 179-190.

= I. HODDER: Wheels of time: Some aspects of entanglement theory and the secondary products revolution. JWP 24/4 (2011) 175-187.

= T. HoRvÁTH: A szárazföldi szállítás kezdete és hatása a Boleráz/Baden kultúrák életében (The dawn and the impact of overland transport in the life of Boleráz/Baden culture). JAMÉ 52 (2010) 95-139. 
IVANOVA 2007

IVANOVA 2012

JEUNESSE 2006

JOHANNSEN-LAURSEN 2010

KALICZ 1963

KENOYER 2004

KIRTCHO 2009

KoHL 2007

KoOIJMAns 2006

KOREK 1951

KOREK 1980

KORKUTI 2008

KRUK-MILISAUSKAS 1982

KUZ’MINÁ 2007

LARSSON 2004

LAW 2006

LEVINE 1999

LIBBY 1952

LING-ÚHNÉR 2014

LITTAUER-CROUWEL 1974

LITTAUER-CROUWEL 1979

LITTAUER-CROUWEL 1990

LiTTAUER-CROUWEL 2002

MARAN 1998

MARAN 2004a

MARAN 2004b

MARCINIAK 2011

MATUSCHIK 2006

MischKa 2010

MISCHKA 2011

MOOREy 1986
= M. IvANOvA: The chronology of the "Maikop culture" in the North Caucasus: changing perspectives. American Journal of Near Estern Studies 2 (2007) 7-39.

= M. Ivanova: Kaukasus und Orient: Die Entstehung des „Maikop-Phänomens” im 4. Jahrtausend v. Chr. PZ 87 (2012) 1-28.

= C. JEUNESSE: Les sépultures de paires de bovins dans le Néolithiques final de l'est et de l'Europe centrale. In: PÉTREQUIN et al. (eds) 2006, 247-258.

$=$ A. N. JOHANNSEN-A. S. LAURSEN: Routes and wheeled transport in late $4^{\text {th }}$-early $3^{\text {rd }}$ millennium funerary customs of the Jutland Peninsula: Regional evidence and European context. PZ 85 (2010) $15-58$.

= N. KALICZ: Die Péceler (Badener) Kultur und Anatolien. StudArch 2. Akadémiai Kiadó, Budapest 1963.

= M. J. Kenoyer: Die Karren der Induskultur Pakistans and Indiens. In: FANSA-BurmeIster (eds) 2004b, 67-106.

$=$ L. B. KIRTCHO: The earliest wheeled transport in Southwestern Central Asia: new finds from AltynDepe. Archaeology, Ethnology and Anthropology of Eurasia 37 (2009) 25-33.

$=$ P. KoHL: The Making of Bronze Age Eurasia. Cambridge world archaeology. Cambridge University Press, Cambridge 2007.

$=$ L. P. L. Koommans: Les débuts de la traction animale aux Pay-Bas et ses conséquences. In: PÉTREQUin et al. (eds) 2006, 191-206.

= J. KoREK: Ein Gräberfeld der Badener Kultur bei Alsónémedi. ActaArchHung 1 (1951) 35-51.

= J. KOREK: Alsónémedi történetének régészeti forrásai a honfoglalás koráig [The archaeological sources of the history of Alsónémedi until the Hungarian Conquest]. In: Alsónémedi története és néprajza Ed.: I. Balassa. Pest megyei falumonográfiák 1. Alsónémedi 1980, 9-47.

= M. KorKUTI: Arti shkëmbor në shqipëri - Rock art in Albania. Instituti i Arkeologjisë, Tiranë 2008.

= J. KRUK-S. MilisausKas: Die Wagendarstellung auf einem Trichterbecher aus Bronocice in Polen. AKorr 12 (1982) 141-144.

= E. E. KUZ'MINA: The Origin of the Indo-Iranians. Leiden Indo-European etymological dictionary series 3. Brill, Leiden 2007.

$=\mathrm{T}$. LARSSON: Streitwagen, Karren und Wagen in der bronzezeitlichen Felskunst Skandinavians. In: FANSA-BURMEISTER (eds) 2004b, 381-398.

$=\mathrm{R}$. LAw: Moving mountains: The trade and transport of rocks and minerals within the Greater Indus Valley region. In: Space and Spatial Analysis in Archaeology. Eds: E. C. Robertson, D. J. Seibert, D. C. Fernandez, M. U. Zender. University of Galgary Press, Galgary 2006, 301-313.

$=$ M. LEVINE: Botai and the origins of horse domestication. Journal of Anthropological Archaeology 18 (1999) 29-78

= W. F. LibBy: Radiocarbon Dating. University of Chicago Press, Chicago 1952

= J. LING-C. ÚHNÉR: Rock art and metal trade. Adoranten 2014, 23-43.

= M. A. LitTAueR-J. H. Crouwel: Terracotta models as evidence for vehicles with tilts in the Ancient Near East. PPS 40 (1974) 20-36.

= M. A. LitTAuer-J. H. Crouwel: Wheeled Vehicle and Ridden Animals in the Ancient Near East. Brill, Leiden 1979.

= M. A. LitTAueR-J. H. Crouwel: A terracotta wagon model from Syria in Oxford. Levant 22 (1990) $160-162$.

= M. A. LitTAuer - J. H. Crouwel: Selected writings on Chariots and other Early Vehicles. Riding and Harness. Ed. by P. Raulwing. Culture and history of the Ancient Near East 6. Brill, Leiden 2002.

= J. MARAN: Die Badener Kultur und der ägäisch-anatolische Bereich. Ein Neubewertung eines alten Forschungs-problems. Germania 76 (1998) 497-525.

= J. MARAN: Die Badener Kultur und ihre Ràderfahrzeuge. In: FANSA-BURMEISTER (eds) 2004b, 265-281.

$=$ J. MARAN: Kulturkontakte und Wege der Ausbreitung der Wagentechnologie im 4. Jahrtausend v. Chr. In: FAnsa-Burmeister (eds) 2004b, 429-442.

= A. MARCINIAK: The secondary products revolution: Empirical evidence and its current zooarchaeological critique. JWP 24 (2011) 117-130

= I. MatuschiK: Irenäus: Invention et diffusion de la roue dans l'Ancien Monde: l'apport de l'iconographie. In: PÉTREQUIN et al. (eds) 2006, 279-297.

= D. MischKA: Flintbek LA 3, biography of a monument. www.jungsteinSITE.de December 20th, 2010.

= D. MischKA: The Neolithic burial sequence at Flintbek LA 3, North Germany, and its cart tracks: a precise chronology. Antiquity 85 (2011) 742-758

$=$ P. R. S. Moorey: The emergence of the light, horse-drawn chariot in the Near-East c. 2000 1500 B.C. WA 18 (1986) 196-215. 
MÜLLER 1921

NADLER 2002

NAGEL 1966

NAGEL 1986

NAGEL 1992

NovotnÝ 1990

NovOZHENOV 2012

ØSTERGAARD 2011

OUTRAM et al. 2011

PAUL et al. 1980

PARE 1989

PÉTREQUin et al. 2006a

PÉTREQUin et al. 2006b

PÉTRequiN-PÉtrequiN-BAILly 2006

PÉTREQuin et al. (eds) 2006

PigGOTt 1974

Piggott 1978

Piggott 1979

PiggotT 1983

PigGotT 1987

Piggott 1992

PRZYBYL 2015

Rad und Wagen 2002

Rad und Wagen 2004

RAULWING 2000

RKM

RoLle 1991
= S. MüLLER: Bronzealderens Kunst. I.: Danmark. Købehavn 1921.

= M. NADLER: Anatolische Impressionen. In: Rad und Wagen 2002, 93-98.

=W. NAGEL: Der mesopotamische Streitwagen und seine Entwicklung im ostmediterranen Bereich. Berliner Beiträge zur Vor- und Frühgeschichte 10. Bruno Hessling Verlag, Berlin 1966.

=W. NAGEL: Die Entwicklung des Wagens im frühen Vorderasien. In: Achse, Rad und Wagen Fünftausende Jahre Kultur- und Technikgeschichte. Hrsg.: W. Treue, Vandenhoeck and Ruprecht, Göttingen 1986, 9-34.

= W. NAGEL: Die Wagentypen des zentral-vorderasiatischen Frühdynastikums und der Bremsbügel. Archäologische Mitteilungen aus Nordwestdeutschland 15 (1992) 167-178.

= B. NovotNÝ: Pokračovanie výskumu na Burchbrichu vo Velkej Lomnici (Forsetzung der Grabung auf Burchbrich in Velká Lomnica). AVANS 1988 (1990) 128.

= V. A. NovozHENOv: Communications and the Earliest Wheeled Transport of Eurasia. TAUS Publishing, Moscow 2012.

$=$ J. S. ØSTERGAARD: A perspective on the secondary products revolution in Bulgaria. Studii de Preistorie 8 (2011) 99-109.

= A. K. Outram-N. A. Stear-A. Kasparov-E. Usmanova-V. Varfolomeev-R. Evershed: Horses for the dead: funerary foodways in Bronze Age Kazakhstan. Antiquity 85 (2011) 116-128.

= M. Paul-W. Henning-E. J. Stephenson-J. L. Yntema: Measurement of the ${ }^{26} \mathrm{Mg}(\mathrm{p}, \mathrm{n})^{26} \mathrm{Al}^{\mathrm{g}}(7.2$ $\times 10^{5}$ ) yr cross section via accelerator mass spectrometry. Physics Letters B 94 (1980) 303-306.

$=$ C. PARE: From Dupljaja to Delphi: the ceremonial use of the wagon in later Prehistory. Antiquity 63 (1989) 80-100.

= P. Pétrequin-R-M. Arbogast-A-M. Pétrequin-S. Van Willigen-M. Bailley: La traction animale au Néolithique: diversité des documents, diversité des aproches. In: PÉTREQUIN et al. (eds) 2006, 11-20.

= P. Pétrequin-M. Pétrequin-R-M. Arbogast-D. Maréchal-A. Viellet: Travois et jougs néolithiques du lac de Chalain à Fontenu (Jura, France). In: PÉTreQuin et al. (eds) 2006, 87-105.

= P. PÉtrequin-A.-M. Pétrequin-M. Bailly: Vues du Jura Français, les premières tractions animals au Néolthique en Europe Occidentale. In: PÉtrequin et al. (eds) 2006, 361-398.

= P. Pétrequin-R.-M. Arbogast-A.-M. Pétrequin-S. Van Willigen-M. Bailly (eds) : Premiers chariots, premiers araires. La diffusion de la traction animale en Europe pendant les IV ${ }^{\grave{e}}$ et III millénaires avant notre ère. CRA monograph 29. CNRS Édition, Paris 2006.

$=$ S. PIGGotT: Chariots in the Caucasus and in China. Antiquity 48 (1974) 16-24.

= S. Piggott: Chinese chariotry: an outsider's view. In: Arts of the Eurasian Steppelands. Ed.: P. Denwood. Percival David Foundation of Chinese Art, London 1978, 32-51.

= S. PiggotT: The First Wagons and Charts: twenty-five years later. BIAL 16 (1979) 3-17.

$=$ S. Piggott: The Earliest Wheeled Transport. From the Atlantic Coast to the Caspian Sea. Thames and Hudson, London 1983.

= S. PiggotT: Az európai civilizáció kezdetei [after: Ancient Europe from the Beginnings of Agriculture to the Classical Antiquity. Edinburgh 1965]. Gondolat, Budapest 1987.

$=$ S. PiggotT: Wagon, Chariot and Carriage. Symbol and Status in the History of Transport. Thames and Hudson. London 1992

= A. PrZYBYL: The Baden complex and the Funnel Beaker culture in the Polish Lowlands. The Problem of "lowland badenization". In: The Baden Culture around the Western Carpathians. Eds: M. Nowak, A. Zastawny. VIA Archaeologica, Kraków 2015, 471-494.

= J. Königer-M. Mainberger-H. Schlichtherle-M. Vosteen (Hrsg.): Rad und Wagen. Zur Frage früher Transportmittel nördlich der Alpen. Hemmenhofener skripte 3. Janus Verlag, Freiburg i Breisgau 2002.

$=$ FANSA-BURMEISTER (eds) 2004a

$=$ P. RAUlwing: Horses, Chariots and Indo-Europeans. Foundations and Methods of Chariotry Research from the Viewpoint of Comparative Indo-European Linguistics. Archaeolingua SerMin 13. Budapest 2000

Régészeti kutatások Magyarországon - Archaeological Investigations in Hungary. Ed.: E. Marton, J. Kisfaludi et al. Budapest 1998-.

= R. Rolle: Städte auf Rädern. Zur Entwicklung des nomadischen Wohnwagens. In: Gold der Steppe. Archäologie der Ukraine. Buch zur Ausstellung: Archäologisches Landesmuseum der ChristianAlbrechts-Universität Schleswig und Archäologisches Institut der Akademie der Wissenschaften der Ukrainischen SSR Kiev in Zusammenarbeit mit dem Seminar für Ur- und Frühgeschichte der Georg-August-Universität Göttingen und dem Institut für Ur- und Frühgeschichte. Hrsg.: R. Rolle, M. Müller-Wille, K. Schietzel. Wachholtz, Neumünster 1991, 185-192. 
RUOFF 2006

SAGONA 2013

SANZ 2005

SAULIEU-SERRES 2006

SCHLICHTHERLE 2006

SCHLICHTHERLE 2010

SHERRATT 1981

SHERRATT 1983

SHERRATT 1997

SHERRATT 2004

SOPRONI 1954

SOPRONI 1956

TARRÚs et al. 2006

TRIFONOV 2004

TURECKIJ 2004

VASIĆ 2004

VELUŠČEK 2002

VELUŠČEK 2006

VosTEEN 1996

VosTEEN 1999

VOSTEEN 2006

WegZeiten 2004

WENINGER et al. 2015

WoyTOVICH 1995

ZICH 1992

ZICH 1993

ZICH 2006
= U. RUOFF: Roues et chars: les plus anciennes découvertes de Suisse. In: PETREQUIN et al. (eds) 2006, 133-140.

= A. SAGonA: Wagons and carts of the Trans-Caucasus. In: Tarhan Armağani. M. Taner Tarhan'a Sunulan Makaleler Essays in Honour of M. Taner Tarhan. Eds: O. Tekin, M. H. Sayar, E. Konyar. Istambul 2013, 277-297.

= F. Q. SANZ: Carros en el antiguo Mediterráneo: de los origenes a Roma. In: Historia del carruaje en España. Ed.: E. Galán. Madrid 2005, 16-71.

= DE G. SAULIEU-T. SerRES: Les représentations de la traction animale dans la région du Mont Bego (Alpes-Maritimes, France). In: PÉTREQuin et al. (eds) 2006, 73-86.

$=$ H. Schlichtherle: Chemins, roues et chariots: innovation de la fin du Néolithique dans le SudOuest de l'Allemagne. In: PÉTREQuin et al. (eds) 2006, 165-178.

$=$ H. SCHLICHTHERLE: Als die ersten Räder rollten ... Räder der Jungsteinzeit aus dem Olzreuter Ried bei Bad Schussenried. Denkmalpflege in Baden-Württemberg 3 (2010) 140-144.

$=$ A. SHERATT: Plough and pastoralism: aspects of the secondary products revolution. In: Pattern of the Past: Studies in honour of David Clarke. Eds: I. Hodder, G. Isaac, N. Hammond. Cambridge University Press, Cambridge 1981, 261-305.

= A. SHERRATT: The secondary exploitation of animals in the Old World. WA 15 (1983) 90-104.

= A. Sherratt: The horse and the wheel: the dialectics of change in the Circum-Pontic region and adjacent areas, 4500-1500 B.C. In: Prehistoric Steppe Adaptation and the Horse. Eds: M. Levine, C. Renfrew, K. Boyle. McDonald Institute monographs. Institute for Archaeological Research, Cambridge 1997, 233-252.

= A. Sherratt: Wagen, Pflug, Rind: ihre Ausbreitung und Nutzung - Probleme der Quelleninterpretation. In: FANSA-BURMEISTER (eds) 2004b, 409-428.

= S. Soproni: A budakalászi kocsi [The wagon of Budakalász]. FolArch 6 (1954) 29-36.

= S. SOPRONI: Budakalász-Luppa csárda. In: BANNER 1956, 111-128.

= J. TARRÚS-M. SAÑA-J. ChINChILlA-Á. Bosch: La Draga (Banyoles, Catalogne): traction animale à la fin du VI ${ }^{\mathrm{e}}$ millénaire? In: PÉTREQUIN et al. (eds) 2006, 25-30.

= V. Trifonov: Die Majkop-Kultur und die ersten Wagen in der südrussischen Steppe. In: FansABURMEISTER (eds) 2004b, 167-176.

= M. A. TURECKIJ: Wagengräber der grubengrabzeitlichen Kulturen im Steppengebiet Osteuropas. In: FANSA-BURMEISTER (eds) 2004b, 191-200

$=$ R. VAsıć: The Dupljaja cart again. In: Festschrift für Florin Medeleţ. Zum 60. Geburtstag. Hrsg. P. Rogozea, V. Cedică. Bibliotheca historica et archaeologica Banatica 32. Editura Minton, Timişoara 2004, 155-162.

= A. VELUŠČEK: Ostanki eneolitskega voza z Ljubljanske barja (The remains of an Eneolithic cart from the Ljubljana Marshes). AV 53 (2002) 51-57.

= A. VELUŠČEK: Une roue et un essieu néolithiques dans le marais de Ljubljana (Slovénie). In: PÉTREQuin et al. (eds) 2006, 39-45.

= M. VosteEn: Unter die Räder gekommen. Untersuchungen zu Sherratts ,Secondary products revolution". Archäologische Berichte 7. Holos Verlag, Bonn 1996.

= M. VosteEn: Urgeschichtliche Wagen in Mitteleuropa. Eine ärchäologische und religionswissenschaftliche Untersuchung neolithischer bis hallstattzeitlicher Befunde. Freiburger archäologische Studien 3. Verlag Marie Leidorf, Rahden 1999.

= M. VosteEn: Une double invention: véhicules à roues et traction animale. In: PÉTREQUIN et al. (eds) 2006, 239-246.

= WegZeiten. Archäologie und Strassenbau. Begleitbuch zur Ausstellung des Bundesdenkmalamtes, Abteilung für Bodendenkmale in Kooperation mit der Niederösterreichischen Landesregierung, Gruppe Straße in der Kartause Mauerbach, 20. Mai bis 30. September 2004. FÖ-Materialhefte A, Sonderheft 1.Wien 2004

$=$ B. WENINGER-C. LEE-O. JÖRIS-R. JUNG-K. EDINBOROUGH: Quantum theory of radiocarbon calibration. WA 29 Jul 2015. Published on-line

= E. Woytovich: Die Wagen der Schweiz in der europäischen Bronzezeit. HelvA 26 (1995) 83-351.

= B. ZICH: Frühneolitische Karrenspuren in Flintbek. Archäologie in Deutschland 8 (1992) 58.

= B. ZICH: Die Ausgrabungen chronisch gefährdeter Hügelgräber der Stein- und Bronzezeit in Flintbek, Kreis Rendsburg-Eckenhörde. Ein Vorbericht. Offa 49-50 (1993) 15-31.

= B. ZICH: Ornières de véhicules néolithiques à Flintbek (Allemagne du Nord). In: PÉTREQUIN et al. (eds) 2006, 215-224 
